\title{
The Partisan Mask: Political Orientation, Collectivism, and Religiosity Predict Mask Use During COVID-19
}

\author{
Hohjin Im ${ }^{1 *} \mid$ Peiyi Wang ${ }^{1}$ Chuansheng Chen ${ }^{1}$ \\ ${ }^{1}$ University of California Irvine $\mid *$ Corresponding author email: $\underline{\text { hohjini@uci.edu. }}$
}

\begin{abstract}
A B S T R A C T
In the United States, the COVID-19 pandemic became an unconventional vehicle to advance partisan rhetoric and antagonism. Using data available at the individual- (Study 1; $\mathrm{N}=4,220$ ), county- (Study 2; $\mathrm{n}=3,046$ ), and state-level $(n=49)$, we found that partisanship and political orientation was a robust and strong correlate of mask use. Political conservatism and Republican partisanship were related to downplaying the severity of COVID-19 and perceiving masks as being ineffective that, in turn, were related to lower mask use. In contrast, we found that counties with majority Democrat partisanship reported greater mask use, controlling for various socioeconomic and demographic factors. Lastly, states with strong cultural collectivism reported greater mask use while those with strong religiosity reported the opposite. States with greater Democrat partisanship and strong cultural collectivism subsequently reported lower COVID-19 deaths, mediated by greater mask use and lower COVID-19 cases, in the five months following the second wave of COVID-19 in the US during the Summer of 2020. Nonetheless, more than the majority for Democrats $(91.58 \%)$, Republicans $(77.52 \%)$, and third-party members $(82.48 \%)$ reported using masks. Implications for findings are discussed.
\end{abstract}

KEYWORDS: COVID-19; mask; partisanship; political; conservatism; collectivism; religiosity

\section{INTRODUCTION}

"To abolish mask-wearing laws in some States while the rest of the Nation keeps theirs is like designating a peeing section of the swimming pool." - Neil DeGrasse Tyson

Since its first discovery in late 2019, COVID-19 has infected more than 100 million people worldwide. By Spring of 2020, the United States (US) became the largest hotbed for COVID-19 cases and has remained since, with a sizeable plurality of the total worldwide cases and grimly boasting the highest cases of related deaths of any country (Johns Hopkins Coronavirus Resource Center, 2020). In the absence of a viable vaccine, governments have implemented traditional public health interventions, such as using masks (Cheng et al., 2020; Eikenberry et al., 2020; Liang et al., 2020; Liu \& Zhang, 2020). Despite evidence of the efficacy of masks in reducing viral spread, however, its use in the US greatly varied from county to county (Katz et al., 2020) potentially jeopardizing its benefits (Eikenberry et al., 2020). As of October 2020, more than half the states had implemented some form of mask mandate (Markowitz, 2020). Nonetheless, notable cross-sections of the US population have been steadfast in their opposition of mask mandates. Although several studies have since been put forth examining the socioeconomic (Kavanagh et al., 2020), political (Gollwitzer et al., 2020; Kushner Gadarian et al., 2020), cultural (Biddlestone et al., 2020; Huynh, 2020; Im \& Chen, 2020), and psychological correlates of social distancing and other preventive health behaviors (Im et al., 2020; Oosterhoff \& Palmer, 2020), the antecedents and correlates of mask use remains relatively understudied.

\section{Partisanship and Political Orientation on Mask Wearing}

The first and primary goal of this paper is to examine the role of partisanship and political orientation in promoting or dissuading mask use. The US Center for Disease Control (CDC) issued a nation-wide recommendation for the public to use facial coverings in April 2020 (CDC, 2020). However, key Republican leaders did not endorse the use of masks until much later (Adolph et al., 2020; Bosman, 2020), if at all. Set in historically polarized times, the issue of wearing a mask in public became an unconventional vehicle for advancing partisan ideology amid the pandemic. Proponents of 
masks, comprised largely by Democrats and political liberals, argued that facial coverings were crucial to curbing the spread of COVID-19 and was a simple method by which one may uphold their social responsibility towards public safety (McKelvey, 2020). On the other end, opponents, comprised largely by Republicans and conservatives, have argued that such policies infringed on their civil rights and symbolized government oppression (Edsall, 2020; Rantz, 2020).

While the rhetoric put forth by the two competing parties hinged largely on social responsibility and individual freedom, the pattern of mask endorsement or opposition is reminiscent of historic differences across party lines regarding preventive health behaviors in general. Republicans and conservatives are typically less likely to seek out health information or obtain flu vaccinations (Kannan \& Veazie, 2018) and hold less positive attitudes toward health promotion (Bellas et al., 2000). Accordingly, a partisan divide in COVID-19 preventive health measures became evident in recent studies (Kushner Gadarian et al., 2020), ranging from Republicans' or conservatives' lower intentions to wash their hands (Everett et al., 2020), resistance to comply with shelter at home orders (Allcott et al., 2020; Gollwitzer et al., 2020; Grossman et al., 2020; Hsiehchen et al., 2020; Im et al., 2020), and tendency to perceive lower risk toward COVID-19 (Bruine de Bruin et al., 2020; CIVIQS, 2020; Gallup, 2020; Weiss \& PaascheOrlow, 2020). Further, Fox News viewership (commonly right-leaning media) was also related with reduced intentions to shelter-in-place (Simonov et al., 2020).

As a direct consequence of the harsh polarization of partisan ideology rampant in the current sociopolitical ecology, party contingents on both sides may find themselves trapped inside echo chambers where their values, preferences, and attitudes are recirculated amongst one another (Van Bavel et al., 2020; Van Bavel \& Pereira, 2018), amplifying their convictions from mere opinions to objective truths. Hence, based on the existing literature, we posit the following:

Hypothesis 1a: Political Conservatism is negatively associated with mask use.

Hypothesis 1b: Republican partisanship is negatively associated with mask use.

\section{Collectivism on Mask Wearing}

The secondary goal of this paper is to explore the role of culture in mask use. Although culture's role in infection control has only recently garnered attention among the scholarly community (Borg, 2014; Gaygisız et al., 2017; Van Bavel et al., 2020), the connection between culture and mask-wearing has long been one of anecdotal interest among the public (Wong, 2020). Historical and modern accounts would suggest that the high prevalence of recent deadly diseases in these regions (e.g., 2002 SARS outbreak, 2006 bird flu, and 2012 MERS epidemic), annual meteorological phenomena (e.g., Yellow Dust in South Korea), and poor quality of air (e.g., air pollution in urban areas of China) resulted in the widespread adoption of masks in East Asia. However, the US likewise suffered from the $2009 \mathrm{H} 1 \mathrm{~N} 1$ epidemic and many metropolitan cities (e.g., Los Angeles, New York City) continue to have poor air quality from smog or wildfires yet have largely failed to mirror their Eastern counterparts in adopting the widespread use of masks.

The collectivism-individualism dynamic most popularly differentiates Eastern and Western countries and has rightfully garnered attention in explaining preventive behavioral differences. Collectivism is the degree to which a culture endorses values of interdependence and community whereas individualism is the valuation of the independent agent over the group (Hofstede et al., 2010; Triandis, 2001). Thus, collectivist cultures may sense greater social responsibility for the collective's well-being. Early research of collectivism's role in COVID-19 documented a positive link between collectivism and engagement in preventive health across individuals (Biddlestone et al., 2020), states ( $\mathrm{Im}$ et al., 2020), and countries (Im \& Chen, 2020). Indeed, social responsibility has been evidenced in early research to be a strong precursor to social distancing and disinfecting behaviors (Oosterhoff et al., 2020; Oosterhoff \& Palmer, 2020). To the extent that collectivism increases social responsibility and promotes preventive behavior, regions with high collectivism may be more receptive to mask use in the US. Thus, we posit the following:

Hypothesis 2: Collectivism is positively associated with mask use.

\section{Religion on Mask Wearing}

The third goal of this paper was to examine the role of religiosity on mask use. Although the majority of religious groups and centers have since been innovative and compliant in adhering to health regulations (Wildman et al., 2020), religious places of worship were quickly flagged as hotspots for COVID-19 in the infant stages of the pandemic. In South Korea, the first cluster of outbreaks of COVID-19 was largely connected to the Shincheonji (신천지) Church of Jesus and more recently, the Sarang Jeil Church (사랑제일교회) has been criticized for sparking another cluster of cases (BBC, 2020). High prevalence of COVID-19 cases has been linked to the continued provision of in-person religious services in defiance of local or federal policies (Jaja et al., 2020; Noyes, 2020; Shin, 2020; Vermeer \& Kregting, 2020). Early evidence also points to greater defiance of shelter-in-place directives among areas with greater 
religiosity (Jaja et al., 2020) as such policies may be regarded as restricting one's religious freedom to congregate (DeFranza et al., 2020). The relation between religiosity and mask-adherence, however, requires further research.

Although some have explicitly argued that wearing masks is in defiance of God (e.g., Fieldstadt, 2020), the tendency for ardent religious followers to oppose mask policies is likely to parallel the motives of far-right political parties. Indeed, values of Christian nationalism, many of which coincide with far-right conservative rhetoric, were found to obstruct adoption of preventive behaviors (Perry et al., 2020). Even in the absence of inperson religious service attendance, however, the roots of religiosity can run deep in the weaves of social culture, influencing the ways in which the public responds to the virus (Vermeer \& Kregting, 2020). Given that the majority of the United States religious body is Christian, it is likely that the religious zealotry captures some essence of extreme nationalism documented in Perry et al. (2020). Thus, regions marked by strong religiosity may be less receptive to adopting the use of masks. For these reasons, we posit the following:

Hypothesis 3: Religiosity is negatively associated with mask use.

\section{Socioeconomic Demographics and Health on Mask Wearing}

In examining the effects of political orientation, culture, and religion on mask use, however, it remains the need to consider and control for several possible confounding variables. The advent of COVID-19 has also shed light on the severity of the abundant socioeconomic inequities in the American society that pose dangerous risks for the spread of infectious diseases. Indeed, in the past, the level of adherence to preventive measures, health knowledge, and attitudes toward infectious diseases (e.g., H1N1 influenza) were directly linked to educational attainment (Janahi et al., 2011; Latiff et al., 2012; Lin et al., 2011; Singh et al., 2012). Further, highly educated individuals tended to demonstrate less HIV risky behaviors (Thanh et al., 2009) and were more responsive to the HIV/AIDS information campaigns that aimed to disseminate HIV/AIDS knowledge (Walque, 2004). Pertaining to COVID-19, studies have found that education attainment was positively associated with greater sensitivity to government and media issued information about preventive behaviors (Roy et al., 2020) and better reduced physical movement during the first wave of the pandemic (Im et al., 2020).

Moreover, income inequality poses a significant risk to the COVID-19 pandemic. On the one hand, income inequality has been documented to influence social capital and trust in the government (Twenge et al., 2014), which, in turn, influences the adoption of preventive behavior in the fight against infectious diseases. During the H1N1 pandemic, those who resided in areas with higher social capital tended to trust the government more and adopted health preventive behaviors, such as vaccination (Gilles et al., 2011; Jung et al., 2013; Liao et al., 2010). On the other hand, even if individuals in lower income areas wished to engage in preventive behaviors, several systematic limitations prohibit them from doing so. Lower income neighborhoods observed significantly lower physical distancing than their upper income counterparts due to greater need to work in-person jobs (Jay et al., 2020). Further, greater income inequality has been noted to be related to the reduced coverage of preventive resources (Nagaoka et al., 2012) that may consequently influence the public's adoption of similar behaviors. This is, in part, broadly beset by the general trend for income inequality to be related to greater risky behavior stemming from a psychological sense of insecurity associated with financial instability (Payne et al., 2017).

Lastly, prior evidence of health behavior and health status is likely to be important to consider in understanding mask use. Engagement in health promoting habits, for instance, reflects one's health knowledge (Kim et al., 2008), value on health and health self-efficacy (Jackson et al., 2007), which in turn could have associations with individuals' active utilization of preventive health measures (i.e., mask wearing) amidst COVID-19. Additionally, averaged poor health status within a given area might be due to people's clustered practices of health-compromising behavior (e.g., smoking and physical inactivity; Weaver et al., 2013) and their underestimation of disease severity and infection rate. Therefore, poor health status might inversely link to mask adherence, even though evidence also shows that, at the individual level, lower self-rated health status is associated with higher flu vaccination rate (Watson \& Oancea, 2020). To the extent that socioeconomic factors and health behaviors will significantly influence mask use among the populace, such variables would be important to control for in the examination of the roles of political and social values underlying the motivation to wear masks.

\section{Study 1: Political Orientation Differences in Mask Use}

The first study utilized a large, nationally representative dataset to address the first goal of the paper; to examine the link between political orientation and partisanship with mask use. Given the polarized divide between partisan parties in their rhetoric towards COVID-19, endorsement of protective measures, and perceived risks associated with COVID-19 (e.g., Bruine de Bruin et al., 2020; Gollwitzer et al., 2020), the current study examined 
Table 1. Descriptive Statistics and Bi-variate Correlations

\begin{tabular}{lrrrcccc}
\hline Variable & \multicolumn{1}{c}{ M } & \multicolumn{1}{c}{ SD } & $\mathbf{1}$ & $\mathbf{2}$ & $\mathbf{3}$ & $\mathbf{4}$ & $\mathbf{5}$ \\
\hline 1. Mask Use & 0.845 & 0.362 & - & & & & \\
2. Conservatism & 5.104 & 2.239 & $-0.178^{* * *}$ & - & & \\
3. Mask Effective & 3.374 & 0.743 & $0.191^{* * *}$ & $-0.146^{* * *}$ & - & & \\
4. COVID-19 Likelihood & 23.830 & 21.238 & $0.040^{* *}$ & $-0.129^{* * *}$ & $0.064^{* * *}$ & - & \\
5. COVID-19 Contagion & 2.738 & 0.450 & $0.160^{* * *}$ & $-0.245^{* * *}$ & $0.256^{* * *}$ & $0.188^{* * *}$ & - \\
\hline
\end{tabular}

Note: ${ }^{* *} p<0.01 ; * * * p<0.001$; Mask Use correlations indicate point-biserial correlation

how political orientation and partisanship also influence views that may subsequently motivate or dissuade the utilization of masks. To accomplish this, we examined a large dataset collected from April to May 2020. This allowed us to examine the correlates of mask use behavior prior to the widespread legal mandates for mask use were instituted across states amid the onset of the second wave of COVID-19 during the summer of 2020.

\section{Method}

\section{Sample}

Two datasets from the Understanding America Study program (https://uasdata.usc.edu/index.php) were examined; 1) the Coronavirus Tracking Survey (UAS 242) completed by a total of 6,403 respondents from April 29 to May 26, 2020 and 2) the Current News and Caregiving module (UAS 221) completed by a total of 6,154 respondents from January 15-28, 2020. The final sample included 5,260 adults aged between 18 and $101(\mathrm{M} \pm$ $\left.\mathrm{SD}_{\text {age }}=51.375 \pm 15.947\right)$ who completed both surveys. Participant political orientation was taken from the UAS 221 survey and all other variables from the UAS 242 survey. The sample consisted of approximately $57.5 \%$ females and included participants of various ethnic minority backgrounds $(9.4 \%$ Black, $5.2 \%$ Native American, $6.3 \%$ Asian, $1.7 \%$ Pacific Islander). Approximately $56.6 \%$ of the sample were employed at the time of data collection and the average household income was approximately $\$ 40,000$ to 49,999 . Respondents also reported their current subjective health according to the day of response on a 100-point linear scale $(0=$ worst health you can imagine, $100=$ best health you can imagine). Subjective health ranged from 0 to 100 ( $\mathrm{M} \pm$ $\left.\mathrm{SD}_{\text {health }}=77.633 \pm 18.375\right)$.

\section{Measures}

Liberalism-Conservatism. Respondents' level of political liberalism and conservatism was determined with a single item asking where the participant placed themselves on the political spectrum regardless of their political registration or affiliation on a 9-point Likert scale $(1=$ Extremely Liberal, $9=$ Extremely Conservative $)$.

Political Party Membership. Respondents' political party membership was determined with a single item asking which political party the participant most aligned themselves with regardless of their voter registration. Party membership was coded as $1=$ Democrat, $2=$ Republican, and $3=$ Other (e.g., Independent, Libertarian, Green Party, etc.).

Mask Use. Respondents' mask adherence behavior was determined with a single item asking whether the respondent had "worn a mask or other face covering" within the last seven days to keep themselves safe from the novel coronavirus. The item was measured via a dichotomous response scale $(1=y e s, 0=n o)$.

Perception of Mask Effectiveness. Respondents' perceived sense of mask effectiveness was determined with a single item asking the extent to which they believed that "wearing a face mask such as the one shown [N95 Mask Shown]" would be effective in keeping them safe from the novel coronavirus. The item was measured on a 4-point Likert scale $(1=$ Extremely Ineffective, $2=$ Somewhat Ineffective, 3 = Somewhat Effective, $4=$ Extremely Effective).

Perception of COVID-19 Likelihood. Respondents' perceived sense of COVID-19 susceptibility was measured with a single item asking what percent chance they believe it is that they "will get the coronavirus in the next three months." The item was measured on a visual linear scale ranging from $0 \%$ to $100 \%$.

Perception of COVID-19 Contagion. Respondents' perceived sense of COVID-19 danger was measured via eleven items assessing their perceived safety in routine activities (e.g., "Grocery shopping," "Dining in at restaurants," "Visiting with relatives or friends in their home"). The items were measured via a 4-point Likert scale $(1=$ Extremely Safe, 2 = Somewhat Safe, $3=$ Somewhat Unsafe, $4=$ Extremely Unsafe), $\omega=0.824$.

\section{Results}

Descriptive statistics are given in Table 1. Mask use was negatively correlated with political conservatism while positively associated with perceptions of mask 
Table 2. Multilevel Regression Models for Mask Adherence

\begin{tabular}{|c|c|c|c|c|c|}
\hline & $\begin{array}{c}\text { Model } 1 \\
\text { (Mask) }\end{array}$ & $\begin{array}{c}\text { Model } 2 \\
\text { (Mask Eff) }\end{array}$ & $\begin{array}{c}\text { Model } 3 \\
(\text { COVID \%) }\end{array}$ & $\begin{array}{c}\text { Model } 4 \\
\text { (Contagion) }\end{array}$ & $\begin{array}{c}\text { Model } 5 \\
\text { (Mask) }\end{array}$ \\
\hline Predictors & $\beta(95 \%$ CI $)$ & $\beta(95 \%$ CI $)$ & $\beta(95 \%$ CI $)$ & $\beta(95 \%$ CI $)$ & $\beta(95 \%$ CI $)$ \\
\hline Intercept & $\begin{array}{c}1.699 * * * \\
(1.455-1.943)\end{array}$ & $\begin{array}{c}-0.018 \\
(-0.057-0.022)\end{array}$ & $\begin{array}{c}0.037 * \\
(-0.003-0.078)\end{array}$ & $\begin{array}{c}0.005 \\
(-0.028-0.038)\end{array}$ & $\begin{array}{c}1.808 * * * \\
(1.560-2.056)\end{array}$ \\
\hline Health & $\begin{array}{c}0.056 \\
(-0.036-0.148)\end{array}$ & $\begin{array}{c}0.045 * * \\
(0.013-0.076)\end{array}$ & $\begin{array}{c}-0.128 * * * \\
(-0.159--0.097)\end{array}$ & $\begin{array}{c}-0.066 * * * \\
(-0.095--0.036)\end{array}$ & $\begin{array}{c}0.080 \\
(-0.017-0.178)\end{array}$ \\
\hline Gender & $\begin{array}{c}-0.120 * \\
(-0.213--0.027)\end{array}$ & $\begin{array}{c}-0.109 * * * \\
(-0.140--0.078)\end{array}$ & $\begin{array}{c}-0.073 * * * \\
(-0.103--0.043)\end{array}$ & $\begin{array}{c}-0.080 * * * \\
(-0.109--0.051)\end{array}$ & $\begin{array}{c}-0.065 \\
-0.164-0.034)\end{array}$ \\
\hline Education & $\begin{array}{c}0.094 \\
(-0.009-0.197)\end{array}$ & $\begin{array}{c}0.005 \\
(-0.029-0.039)\end{array}$ & $\begin{array}{c}-0.010 \\
(-0.043-0.024)\end{array}$ & $\begin{array}{c}-0.060 * * * \\
(-0.092--0.028)\end{array}$ & $\begin{array}{c}0.101 \\
(-0.008-0.210)\end{array}$ \\
\hline Working Status & $\begin{array}{c}0.066 \\
(-0.041-0.173)\end{array}$ & $\begin{array}{c}-0.001 \\
(-0.037-0.034)\end{array}$ & $\begin{array}{c}0.029 \\
(-0.006-0.064)\end{array}$ & $\begin{array}{c}-0.027 \\
(-0.061-0.006)\end{array}$ & $\begin{array}{c}0.067 \\
(-0.047-0.180)\end{array}$ \\
\hline Household Income & $\begin{array}{c}0.084 \\
(-0.025-0.193)\end{array}$ & $\begin{array}{c}-0.009 \\
(-0.044-0.027)\end{array}$ & $\begin{array}{c}-0.002 \\
(-0.037-0.033)\end{array}$ & $\begin{array}{c}-0.052 * * \\
(-0.085--0.018)\end{array}$ & $\begin{array}{c}0.099 \\
(-0.016-0.214)\end{array}$ \\
\hline Age & $\begin{array}{c}0.364 * * * \\
(0.255-0.473)\end{array}$ & $\begin{array}{c}0.121 * * * \\
(0.085-0.156)\end{array}$ & $\begin{array}{c}-0.042 * \\
(-0.077--0.007)\end{array}$ & $\begin{array}{c}0.088 * * * \\
(0.054-0.122)\end{array}$ & $\begin{array}{c}0.300 * * * \\
(0.184-0.415)\end{array}$ \\
\hline Hispanic/Latino & $\begin{array}{c}0.141 * \\
(0.009-0.273)\end{array}$ & $\begin{array}{c}0.066 * * * \\
(0.032-0.099)\end{array}$ & $\begin{array}{c}0.022 \\
(-0.012-0.055)\end{array}$ & $\begin{array}{c}0.137 * * * \\
(0.106-0.169)\end{array}$ & $\begin{array}{c}0.075 \\
(-0.064-0.213)\end{array}$ \\
\hline Black & $\begin{array}{c}0.169 * * \\
(0.052-0.286)\end{array}$ & $\begin{array}{c}0.027 \\
(-0.004-0.057)\end{array}$ & $\begin{array}{c}-0.041 * * \\
(-0.072--0.011)\end{array}$ & $\begin{array}{c}0.105 * * * \\
(0.076-0.134)\end{array}$ & $\begin{array}{c}0.139 * \\
(0.015-0.262)\end{array}$ \\
\hline Native American & $\begin{array}{c}-0.032 \\
(-0.125-0.061)\end{array}$ & $\begin{array}{c}-0.007 \\
(-0.037-0.024)\end{array}$ & $\begin{array}{c}0.014 \\
(-0.016-0.044)\end{array}$ & $\begin{array}{c}-0.009 \\
(-0.038-0.020)\end{array}$ & $\begin{array}{c}-0.028 \\
(-0.125-0.070)\end{array}$ \\
\hline Asian & $\begin{array}{c}0.014 \\
(-0.104-0.133)\end{array}$ & $\begin{array}{c}0.057 * * * \\
(0.026-0.089)\end{array}$ & $\begin{array}{c}0.005 \\
(-0.027-0.036)\end{array}$ & $\begin{array}{c}0.083 * * * \\
(0.053-0.113)\end{array}$ & $\begin{array}{c}-0.038 \\
(-0.163-0.086)\end{array}$ \\
\hline Pacific Islander & $\begin{array}{c}-0.002 \\
(-0.102-0.097)\end{array}$ & $\begin{array}{c}-0.001 \\
(-0.032-0.029)\end{array}$ & $\begin{array}{c}0.017 \\
(-0.013-0.047)\end{array}$ & $\begin{array}{c}-0.018 \\
(-0.047-0.011)\end{array}$ & $\begin{array}{c}-0.001 \\
(-0.106-0.103)\end{array}$ \\
\hline Conservatism & $\begin{array}{c}-0.453 \text { *** } \\
(-0.556--0.349)\end{array}$ & $\begin{array}{c}-0.140 * * * \\
(-0.172--0.108)\end{array}$ & $\begin{array}{c}-0.117 * * * \\
(-0.149--0.085)\end{array}$ & $\begin{array}{c}-0.220 * * * \\
(-0.250--0.190)\end{array}$ & $\begin{array}{c}-0.324 * * * \\
(-0.435--0.213)\end{array}$ \\
\hline Mask Effectiveness & & & & & $\begin{array}{c}0.395 * * * \\
(0.303-0.487)\end{array}$ \\
\hline COVID \% & & & & & $\begin{array}{c}0.016 \\
(-0.086-0.118)\end{array}$ \\
\hline COVID Danger & & & & & $\begin{array}{c}0.250 * * * \\
(0.149-0.350)\end{array}$ \\
\hline Random Effects & & & & & \\
\hline$\sigma 2$ & 3.29 & 0.93 & 0.94 & 0.83 & 3.29 \\
\hline$\tau 00_{\text {state }}$ & 0.50 & 0.00 & 0.00 & 0.00 & 0.49 \\
\hline ICC & 0.13 & 0 & 0 & 0 & 0.13 \\
\hline $\mathrm{N}_{\text {state }}$ & 51 & 51 & 51 & 51 & 51 \\
\hline Observations & 4202 & 4051 & 4215 & 4195 & 4042 \\
\hline $\begin{array}{l}\text { Marginal } \mathrm{R}^{2} / \\
\text { Conditional } \mathrm{R}^{2}\end{array}$ & $0.085 / 0.205$ & $0.048 / 0.051$ & $0.048 / 0.051$ & $0.124 / 0.125$ & $0.135 / 0.248$ \\
\hline
\end{tabular}

Note: $* p<0.05, * * p<0.01, * * * p<0.001$; Models 1 and 5 are multilevel logistic regression (see Appendix Table A for odds ratios); Variables in parentheses indicate outcome variables; Mask = Mask adherence; Mask Eff = Perceived mask effectiveness; COVID \% = Perception of COVID-19 susceptibility likelihood; Danger = Perception of COVID-19 danger.

effectiveness, predicted likelihood of contracting COVID-19, and perceived contagiousness of COVID-19. The three attitude and perception variables toward mask and COVID-19 were all positively correlated with one another while negatively correlated with political conservatism. All non-binary variables showed low deviation from normality (skewness ranged from -1.461 to 0.826 and kurtosis ranged from -1.176 to 2.157 ).
A series of multilevel logistic (Models $1 \&$ 5; Table 2) and linear regression (Models 2-4; Table 2) analyses were conducted to examine the correlates of mask adherence using two-tail tests. After controlling for demographic variables, conservatism was expectedly negatively associated with mask adherence as well as the perceived likelihood of susceptibility to infection, contagiousness of COVID-19, and effectiveness of masks. Perceptions of mask effectiveness and dangerousness of COVID-19 
Figure 1. Multi-Mediation Path Model

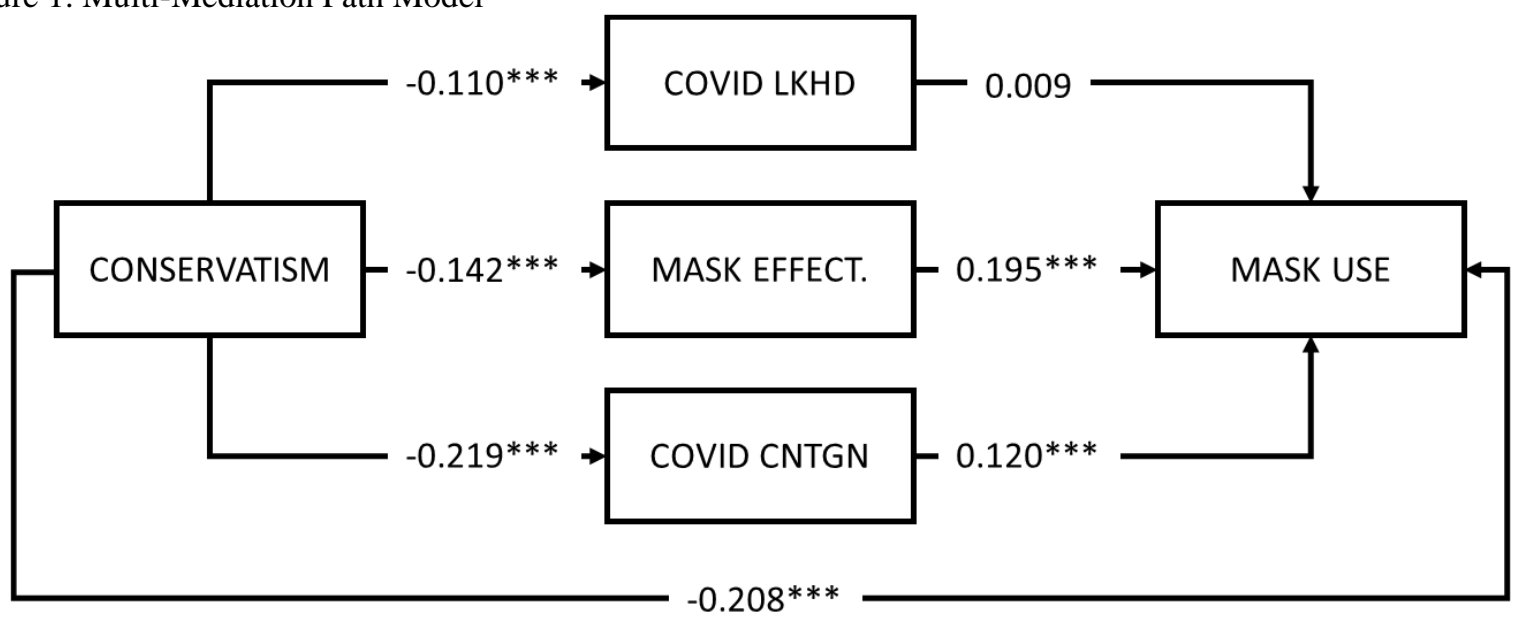

Note: $* * * p<0.001 ; N=4,220$; COVID LKHD = Perception of COVID-19 likelihood; Mask Effect. = Perceived mask effectiveness; COVID CNTGN = Perception of COVID-19 contagiousness; model controlling for subjective health, age, gender, household income, education, working status, and ethnicity.

Table 3. Party Differences Across Study Variables

\begin{tabular}{|c|c|c|c|c|c|}
\hline & Democrat & Republican & Other & & \\
\hline Variable & $\mathbf{M} \pm \mathbf{S D}$ & $\mathbf{M} \pm \mathbf{S D}$ & $\mathbf{M} \pm \mathbf{S D}$ & $\mathbf{F}$ & Pairwise \\
\hline Mask Effectiveness & $3.512 \pm 0.673$ & $3.252 \pm 0.791$ & $3.309 \pm 0.751$ & 43.088 & $\mathrm{D}>\mathrm{R} / \mathrm{O}$ \\
\hline Susceptibility & $25.790 \pm 21.285$ & $21.127 \pm 20.408$ & $24.337 \pm 21.917$ & 22.983 & $\mathrm{D}>\mathrm{O}>\mathrm{R}$ \\
\hline Contagion & $2.845 \pm 0.393$ & $2.610 \pm 0.475$ & $2.737 \pm 0.459$ & 30.092 & $\mathrm{D}>\mathrm{O}>\mathrm{R}$ \\
\hline
\end{tabular}

Note: ANCOVA comparisons conducted controlling for subjective health, age, gender, household income, education, working status, and ethnicity; post-hoc comparison with Tukey correction; all pairwise comparisons significant at 0.01 .

were both positive correlates of mask adherence but not perceived likelihood of susceptibility to infection ( $p=$ 0.755). All models showed low VIF scores of collinearity (range from 1.01 to 1.39).

A structural equation path model clustered by state of residence was conducted to examine the mediating roles of perceptions of COVID-19 susceptibility likelihood, COVID-19 contagiousness, and mask effectiveness (Figure 1). Consistent with findings from the multilevel linear and logistic models, conservatism was negatively associated with mask adherence $(\beta=-0.208,95 \%$ CI [$0.255,-0.16], p<0.001)$, perception of mask effectiveness $(\beta=-0.142,95 \%$ CI $[-0.173,-0.111], p<0.001)$, likelihood of contracting the disease $(\beta=-0.11,95 \%$ CI [$0.142,-0.079], p<0.001)$, and perceived contagiousness of COVID-19 ( $\beta=-0.219,95 \%$ CI $[-0.247,-0.19], p<$ $0.001)$. Mask adherence was positively predicted by perception of mask effectiveness $(\beta=0.195,95 \% \mathrm{CI}$ $[0.153,0.237], p<0.001)$ and perceived contagiousness of COVID-19 $(\beta=0.12,95 \%$ CI $[0.078,0.161], p<0.001)$ but not perceived likelihood of contracting COVID-19 ( $\beta$
$=0.009,95 \%$ CI $[-0.034,0.051], p=0.686)$. Accordingly, perception of COVID-19 susceptibility likelihood did not mediate the effect of conservatism on mask adherence $(\beta$ $=-0.001,95 \%$ CI $[-0.006,0.004], p=0.686)$. However, both perception of mask effectiveness $(\beta=-0.028,95 \%$ CI [-0.036, -0.019], $p<0.001)$ and contagiousness of COVID-19 mediated this effect $(\beta=-0.026,95 \%$ CI [$0.036,-0.016], p<0.001)$.

To examine if the effects of political orientation are also observed at the party level, an ANCOVA was conducted to first examine differences across study variables between party membership (Table 3). Democrats generally tended to perceive greater mask effectiveness, COVID-19 susceptibility likelihood, and contagion than their Republican or third-party counterparts. Republicans reported the lowest perceived likelihood of being infected as well as the lowest level of concern for contagion among the three political parties. Democrats were also approximately $39.8-74.9 \%$ more likely to utilize masks than third-party members while Republicans were 27.1$31.8 \%$ less likely (Appendix Table B). Nonetheless, the 
Figure 2. Conceptual Model

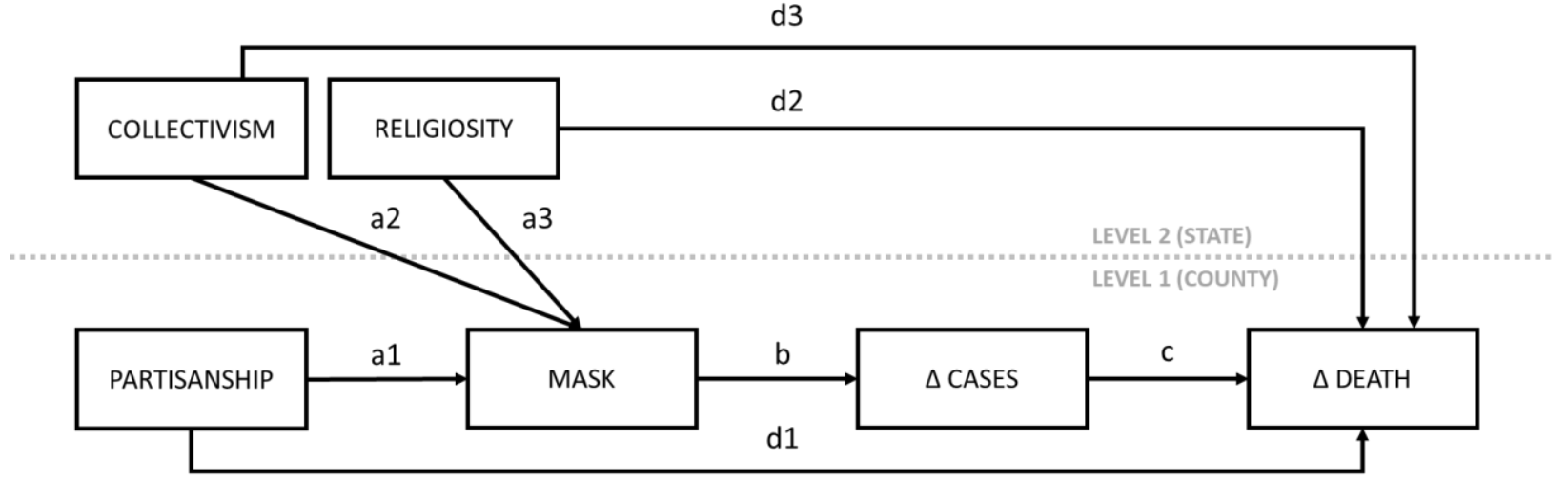

majority of Democrats (91.58\%), Republicans (77.52\%), and third-party members $(82.48 \%)$ reported utilizing masks.

To examine the mediation effects, the same MLM and SEM analyses as Table 2 and Figure 1 were conducted. Democrat and Republican membership were dummy coded with membership in a third party serving as the comparison group. Consistent with findings in Table 2, Democrats were more likely to utilize masks ( $\beta$ from 0.165 to $0.275, p$ from $<0.001$ to 0.006 ) than Republicans ( $\beta$ from -0.114 to $-0.131, p$ from 0.007 to 0.029 ) (see Appendix Table C). Further, Democrats reported greater perception of mask effectiveness $(\beta=0.107, p<0.001)$, COVID-19 contagiousness $(\beta=0.103, p<0.001)$, and susceptibility likelihood $(\beta=0.055, p=0.002)$. On the other hand, Republicans reported significantly less perception of mask effectiveness $(\beta=-0.040, p=0.026)$, COVID-19 contagiousness $(\beta=-0.099, p<0.001)$, and susceptibility likelihood $(\beta=-0.062, p<0.001)$. Consistent with findings with political orientation, the effect of Democrat partisanship on mask use was partially mediated by perceived mask effectiveness ( $\beta=0.019,95 \%$ CI [0.011, 0.027], $p<0.001)$ and COVID-19 contagion ( $\beta$ $=0.013,95 \%$ CI [0.007, 0.019], $p<0.001)$ but not susceptibility $(\beta=0.001,95 \%$ CI $[-0.001,0.003], p=$ 0.470). Likewise, the effect of Republican partisanship on mask use was partially mediated by perceived mask effectiveness ( $\beta=-0.007,95 \%$ CI $[-0.013,-0.001], p=$ $0.021)$ and COVID-19 contagion $(\beta=-0.013,95 \%$ CI [$0.018,-0.007], p<0.001)$ but not susceptibility $(\beta=$ $0.001,95 \%$ CI [-0.003, 0.001], $p=0.467)$.

\section{Discussion}

As expected, the more one is politically conservative, the less they were likely to believe that masks were effective measures against COVID-19, that COVID-19 posed a danger of contagion, and that they were likely to be infected by the disease. However, perceived effectiveness of masks and contagiousness of COVID-19, but not perceived likelihood of contracting COVID-19, in turn promoted mask use. The same pattern of findings was found for partisanship as well. One explanation of why perceived likelihood of contracting COVID-19 was not related to mask use may be that the question did not inquire about perceptions of health threats. That is, even if respondents believed that COVID-19 was highly contagious in general, they may have underplayed the consequences of the virus, akin to how health preventive behaviors may not routinely change during normative influenza seasons. Thus, future research may be necessary to examine if general perception of severity instead serves as a mediating mechanism. Nonetheless, conservatism and Republican membership remained strong negative correlates of mask use, suggesting that even when controlling for mediating mechanisms, political orientation and partisanship can either motivate or dissuade individuals in utilizing masks. It is likely that individuals felt compelled to keep in line with their partisan rhetoric. Thus, conservatives may have opted to endorse the Republican Party's stance on deemphasizing the danger of COVID-19 as well as the efficacy of masks, at least at the time of the current study's data collection. This is in comparison to the Democratic Party's stronger rhetoric calling for widespread use of masks and strict social distancing measures akin to what East Asian countries have put in place in response to the virus. In other words, partisanship is likely to play a critical role in the extent to which masks are utilized and COVID-19 cases and deaths are subsequently controlled.

\section{Study 2: County and State Antecedents and Outcomes of Mask Use}

Results from Study 1 showed that even after controlling for mediators, political orientation and partisanship remained the strong correlates of mask use. Given this, areas with higher proportion of Democrats, and correspondingly lower proportion of Republicans, ought to exhibit greater mask use and subsequently yield 
better COVID-19 outcomes. Study 2 examined the first, second, and third goals of this paper; that political partisanship, collectivism, and religiosity were related to mask use. Further, subsequent outcomes of mask use were also examined. Thus, we examined the indirect effects of Democrat partisanship, cultural collectivism, and religiosity on COVID-19 deaths through the mediating factors of mask use and COVID-19 cases at both the county- and state-level (Figure 2). To accomplish this, we aggregated available data of mask use during early July 2020 and examined proportional changes to COVID-19 cases and deaths in the following five months until December 14, 2020. The date of December 14, 2020 was chosen for two reasons. Firstly, December 14 was when the UK first identified the lineage B.1.1.7 variant (Galloway, 2021) and was approximately two weeks prior to the first US domestic detection of it in Colorado on December 29, 2020 (Pietsch \& Zimmer, 2020). Because this first official reported case was reported to not stem from foreign travel (Pietsch \& Zimmer, 2020), it is reasonable to assume that the B.1.1.7 variant had already been domestically spreading in the US in the two weeks prior to the first discovery. Thus, the two weeks served as a buffer to counter potential latent, confounding effects of the B.1.1.7 variant on disproportionate increases in COVID-19 cases in more urban areas given its higher rate of contagion (Galloway, 2021). Secondly, as the US CDC does not track total cases of new variants by region (CDC, 2021) and local and state reporting standards and procedures of variants may differ, examining proportional changes until December 14 provided the best, reasonable alternative to capture the changes from the height of the Summer 2020 COVID-19 wave to the Fall 2020 COVID19 wave while limiting the latent confounding issues of multiple variants that spread in the US from late Fall 2020 to early Winter 2021 (e.g., B.1.1.7, B.1.351, P.1, etc.).

\section{Methods}

\section{Sample}

The total sample consisted of 3,142 US counties across the 50 states collected from July 2 to July 14 . A total of 96 counties were subsequently removed from the final analysis due to missing data across the relevant measures, resulting in a final sample of 3,046 US counties. Alaska was dropped from the final analyses due to missing data across relevant measures.

\section{Measures: Outcome Variables}

Mask Use. Mask use tendencies were measured via data collected and provided by the New York Times and Dynata (Katz et al., 2020). These aggregated estimates were derived from approximately 250,000 interviews conducted by Dynata from July 2 to July 14 across 3,142 US counties in all 50 states (plus Washington DC) for proper representativeness of each county population. Participants were asked, "How often do you wear a mask in public when you expect to be within six feet of another person?" Participants rated this item from a 5-point Likert scale from 1 (Never), 2 (Rarely), 3 (Sometimes), 4 (Frequently), to 5 (Always). Raw statistics for the proportion of participants choosing each answer were weighted to create a single composite measure of mask adherence by county.

COVID-19 Cases and Deaths. COVID-19 positive cases and deaths came from the USA facts (2021) that tracked the number of cases and deaths at both the state and county level and included as covariates to control for existing levels of COVID-19 prevalence. Because mask use data collection ranged from July 2-14, 2020, statistics for positive cases and deaths as reported on July 2, 2020 were used as control variables. Additionally, COVID-19 cases and deaths on July 14, 2020 was subtracted from their corresponding statistics five months later (December $14,2020)$ and standardized by population to derive a single metric for population-proportional change in cases and deaths.

\section{Measures: Predictor Variables}

Democrat Partisanship. Political orientation data were obtained through the county-level voting results of the 2016 US Presidential Election (Townhall, 2016). The percentage of Democratic party votes was used for each county to determine the political orientation leaning Democrat by each county.

Religiosity. State level religiosity stemmed from the State of the States (Gallup, 2017). For each state reported three indicators of religiosity: 1) \% very religious (percent of residents reporting that religion is important in their lives with weekly attendance of religious services), 2) \% moderately religious (percent of residents reporting that either religion is not important in their lives but regularly attend religious services), 3) \% nonreligious (percent of residents reporting that religion is not important in their lives and do not attend any religious services). The three indicators were then weighted, and a composite religiosity score was calculated.

Collectivism-Individualism. State level collectivism were obtained from Vandello and Cohen (1999). Collectivism scores were aggregated from eight constructs including 1) proportion of single-residents, 2) proportion of elderly single-residents, 3) proportion of households with resident grandchildren, 4) the ratio of divorces to marriages, 5) proportion of secular residents, 6) proportion of Libertarian voters, 7) the ratio of those utilizing carpool to driving alone, and 8) proportion of self-employed workers. 
Table 4. Descriptive Statistics and Correlations

\begin{tabular}{lcccccccc}
\hline Variable & $\mathbf{M}$ & \multicolumn{1}{c}{ SD } & $\mathbf{1}$ & $\mathbf{2}$ & $\mathbf{3}$ & $\mathbf{4}$ & $\mathbf{5}$ & $\mathbf{6}$ \\
\hline 1. Mask & 3.973 & 0.414 & - & & & & & \\
2. Cases & 0.380 & 0.217 & $-0.530^{* * *}$ & - & & & & \\
3. Deaths & 0.582 & 0.427 & $-0.227^{* * *}$ & $0.478^{* * *}$ & - & & & \\
4. Democrat & 0.315 & 0.151 & $0.522^{* * *}$ & $-0.203^{* * *}$ & $-0.080^{* * *}$ & - & & \\
5. Collectivism & 50.122 & 11.450 & $0.437^{* *}$ & $-0.347^{*}$ & -0.014 & $0.367^{* *}$ & - & \\
6. Religiosity & 67.857 & 6.203 & $-0.435^{* *}$ & $0.473^{* * *}$ & $0.613^{* * *}$ & $-0.503^{* * *}$ & $0.326^{*}$ & - \\
\hline
\end{tabular}

Note: Pearson's correlation $r$ variables 1-4 at $\mathrm{n}=3,046$; correlation $r$ variables 5-6 at $\mathrm{n}=49$; COVID-19 cases and deaths are proportional to county-population; $\mathrm{M}$ and SD for COVID-19 cases multiplied by 10 and deaths multiplied by 1,000 .

\section{Measures: Control Variables}

Population Density. County-level population density was calculated by dividing the 2019 county population estimates from the US Census Bureau (2020) divided by the county geographical area. Data for the proportion of older adults (ages 60+) were derived from the 2011-2015 estimates for each county reported by the US Census Bureau (2018).

State Mask Mandates. A dummy coded variable was created to indicate whether the state instituted a mask mandate before or during the data collection period (July $2-14,2020)$. States that recommended wearing masks in public, but did not legally mandate it, were coded as " 0 " while states that had legal mandates were coded as "1".

Education. County-level Education attainment was measured via a weighted proportion of adults with less than high school diploma, high school diploma, some college, and four years of college or more (U.S. Census Bureau, 2019; U.S. Department of Agriculture, 2020).

Income and Income Inequality. Personal income data was from 2018 and were obtained from the US Bureau of Economic Analysis (U.S. Bureau of Economic Analysis, 2019). Income inequality was calculated by the American Community Survey (ACS) and provided by the County Health Rankings dataset (County Health Rankings, 2020). Income inequality was calculated based on the ratio of the $20^{\text {th }}$ and $80^{\text {th }}$ percentile for household income.

Flu Vaccination. County-level vaccination rates were used as proxy variables for routine participation in preventive health behaviors. Vaccination rates were aggregated and provided by County Health Rankings (2020). Vaccination rates against the seasonal flu stemmed from the 2017 MMD data and calculated based on the proportion of Medicare enrollees having record of receiving the annual flu vaccination.

Religious Adherents. County level proportion of religious adherents was included as a covariate to religiosity. Data stemmed from the 2010 US Religion Census: Religious Congregations and Membership Study (Grammich et al., 2018) collected from 2009 to 2011
Religious adherent proportion was calculated as the percentage of population reporting membership in one of 236 religion groups. Approximately $48.8 \%$ of the population reported membership.

\section{Results}

Descriptive statistics are shown in Table 4. As expected, county-level Democrat partisanship and state-level collectivism was strongly and positively associated with self-reported mask use. On the other hand, state-level religiosity was strongly and negatively associated with self-reported mask use. The opposite trends were observed for Democrat partisanship, collectivism, and religiosity in their relation to COVID-19 cases and deaths. Normality tests for the three outcome variables showed heavy skew for COVID-19 cases ( $=3.948)$ and deaths $($ skew $=2.910$, kurtosis $=15.997)$. Normality tests for the three predictor variables showed no variable strongly deviated from normality (skew from -0.111 to 0.964 , kurtosis from -0.542 to 0.722 ).

Three multilevel linear models were conducted to examine the correlates of mask use (Table 5; Model 1), COVID-19 cases (Model 2), and deaths (Model 3) using two-tail tests. Religiosity generally showed moderate negative effects on mask use while Democrat partisanship and collectivism yielded large positive effects, supporting Hypotheses 1b, 2, and 3. Mask use, in turn, was negatively associated with an increase in COVID-19 cases in the five months after collecting data on mask use. Regions marked by high religiosity and collectivism, respectively, observed outbreaks of more and less COVID-19 cases while Democrat partisanship showed no relation. Expectedly, COVID-19 deaths rose with an increase in cases. Consistent with the deviation for normality for COVID-19 cases and deaths, Shapiro-Wilk normality test for the residual of Models $2(\mathrm{~W}=0.881, p<0.001)$ and 3 $(\mathrm{W}=0.817, p<0.001)$ indicate violating the assumption for normality. A robustness check was conducted after applying a ceiling for COVID-19 cases and deaths to remove strong outliers (Appendix Table D). All results 
Table 5. Multilevel Regression Models

\begin{tabular}{|c|c|c|c|}
\hline & $\begin{array}{c}\text { Model 1 } \\
\text { (Mask Use) }\end{array}$ & $\begin{array}{c}\text { Model } 2 \\
\text { (COVID-19 Cases) }\end{array}$ & $\begin{array}{c}\text { Model } 3 \\
\text { (COVID-19 Deaths) }\end{array}$ \\
\hline Predictors & $\beta(95 \%$ CI $)$ & $\beta(95 \%$ CI $)$ & $\beta(95 \%$ CI $)$ \\
\hline Intercept & $\begin{array}{c}0.014 * * * \\
(-0.111-0.138)\end{array}$ & $\begin{array}{c}-0.007 * * \\
(-0.170-0.155)\end{array}$ & $\begin{array}{c}-0.023 \\
(-0.106-0.060)\end{array}$ \\
\hline Population Density & $\begin{array}{c}-0.039 * * * \\
(-0.062--0.016)\end{array}$ & $\begin{array}{c}-0.013 \\
(-0.038-0.013)\end{array}$ & $\begin{array}{c}-0.007 \\
(-0.039-0.024)\end{array}$ \\
\hline Older Adult Proportion & $\begin{array}{c}-0.016 \\
(-0.040-0.008)\end{array}$ & $\begin{array}{c}-0.162 * * * \\
(-0.189--0.135)\end{array}$ & $\begin{array}{c}0.151 * * * \\
(0.118-0.184)\end{array}$ \\
\hline Education Attainment & $\begin{array}{c}0.151 * * * \\
(0.118-0.184)\end{array}$ & $\begin{array}{c}-0.173 * * * \\
(-0.211--0.136)\end{array}$ & $\begin{array}{c}-0.144 * * * \\
(-0.190--0.098)\end{array}$ \\
\hline Personal Income & $\begin{array}{c}0.012 \\
(-0.018-0.042)\end{array}$ & $\begin{array}{c}0.017 \\
(-0.017-0.051)\end{array}$ & $\begin{array}{c}-0.003 \\
(-0.044-0.038)\end{array}$ \\
\hline Income Inequality & $\begin{array}{c}-0.059 * * * \\
(-0.084--0.033)\end{array}$ & $\begin{array}{c}0.068 * * * \\
(0.040-0.097)\end{array}$ & $\begin{array}{c}0.034 \\
(-0.001-0.069)\end{array}$ \\
\hline Religious Adherents & $\begin{array}{c}-0.092 * * * \\
(-0.116--0.067)\end{array}$ & $\begin{array}{c}0.166 * * * \\
(0.139-0.194)\end{array}$ & $\begin{array}{c}0.046 * * \\
(0.011-0.080)\end{array}$ \\
\hline Vaccination Rate & $\begin{array}{c}0.040 * * \\
(0.015-0.066)\end{array}$ & $\begin{array}{c}0.022 \\
(-0.006-0.051)\end{array}$ & $\begin{array}{c}-0.012 \\
(-0.047-0.022)\end{array}$ \\
\hline COVID-19 Cases & $\begin{array}{c}0.004 \\
(-0.022-0.030)\end{array}$ & $\begin{array}{c}0.042 * * \\
(0.014-0.071)\end{array}$ & $\begin{array}{c}-0.026 \\
(-0.062-0.009)\end{array}$ \\
\hline COVID-19 Deaths & $\begin{array}{c}0.046 * * * \\
(0.019-0.074)\end{array}$ & $\begin{array}{c}-0.060 * * * \\
(-0.091--0.029)\end{array}$ & $\begin{array}{c}-0.005 \\
(-0.042-0.033)\end{array}$ \\
\hline Mask Mandate & $\begin{array}{c}0.344 * * * \\
(0.215-0.472)\end{array}$ & $\begin{array}{c}-0.158 \\
(-0.325-0.010)\end{array}$ & $\begin{array}{c}0.001 \\
(-0.089-0.090)\end{array}$ \\
\hline Religiosity & $\begin{array}{c}-0.168 * * \\
(-0.283--0.053)\end{array}$ & $\begin{array}{c}0.234 * * \\
(0.085-0.383)\end{array}$ & $\begin{array}{c}0.000 \\
(-0.086-0.087)\end{array}$ \\
\hline Democrat Proportion & $\begin{array}{c}0.300 * * * \\
(0.271-0.329)\end{array}$ & $\begin{array}{c}0.003 \\
(-0.031-0.038)\end{array}$ & $\begin{array}{c}0.101 * * * \\
(0.059-0.143)\end{array}$ \\
\hline Collectivism & $\begin{array}{c}0.316 * * * \\
(0.195-0.437)\end{array}$ & $\begin{array}{c}-0.355 * * * \\
(-0.511--0.199)\end{array}$ & $\begin{array}{c}0.156 * * \\
(0.063-0.248)\end{array}$ \\
\hline Mask Use & & $\begin{array}{c}-0.109 * * * \\
(-0.148--0.069)\end{array}$ & $\begin{array}{c}-0.021 \\
(-0.069-0.028)\end{array}$ \\
\hline COVID-19 Cases & & & $\begin{array}{c}0.554 * * * \\
(0.512-0.597)\end{array}$ \\
\hline \multicolumn{4}{|l|}{ Random Effects } \\
\hline$\sigma 2$ & 0.05 & 0.00 & 0.00 \\
\hline$\tau 00_{\text {state }}$ & 0.03 & 0.00 & 0.00 \\
\hline ICC & 0.35 & 0.42 & 0.10 \\
\hline $\mathrm{N}_{\text {state }}$ & 49 & 49 & 49 \\
\hline Observations counties & 3046 & 3046 & 3046 \\
\hline Marginal $\mathrm{R}^{2}$ / Conditional $\mathrm{R}^{2}$ & $0.523 / 0.688$ & $0.328 / 0.612$ & $0.357 / 0.421$ \\
\hline
\end{tabular}

Note: $* p<0.05, * * p<0.01, * * * p<0.001$

remained robust and similar to the findings using raw, uncorrected data (Table 5). Unexpectedly, we observed positive direct effects of Democrat partisanship and collectivism on COVID-19 deaths, inconsistent with bivariate correlation results. Although VIF scores showed no evidence of multicollinearity $(1.16-2.19)$, a classic case of Simpson's paradox may explain the reversal in effects. We further examined direct effects in the following mediational analyses.
A multilevel serial mediation model was run to examine the mediating roles of mask use and COVID-19 cases in predicting related deaths (Figure 3). Variables measured at the county-level had latent means intercepts estimated for level 2 (state) mediation analysis. At the county-level, as expected from the multilevel regression model, proportional change in COVID-19 deaths was positively predicted by proportional change in cases $(\beta=0.41,95 \%$ CI [0.38, 0.44], $p<0.001)$. Proportional change in 
Figure 3. Serial Mediation Path Model

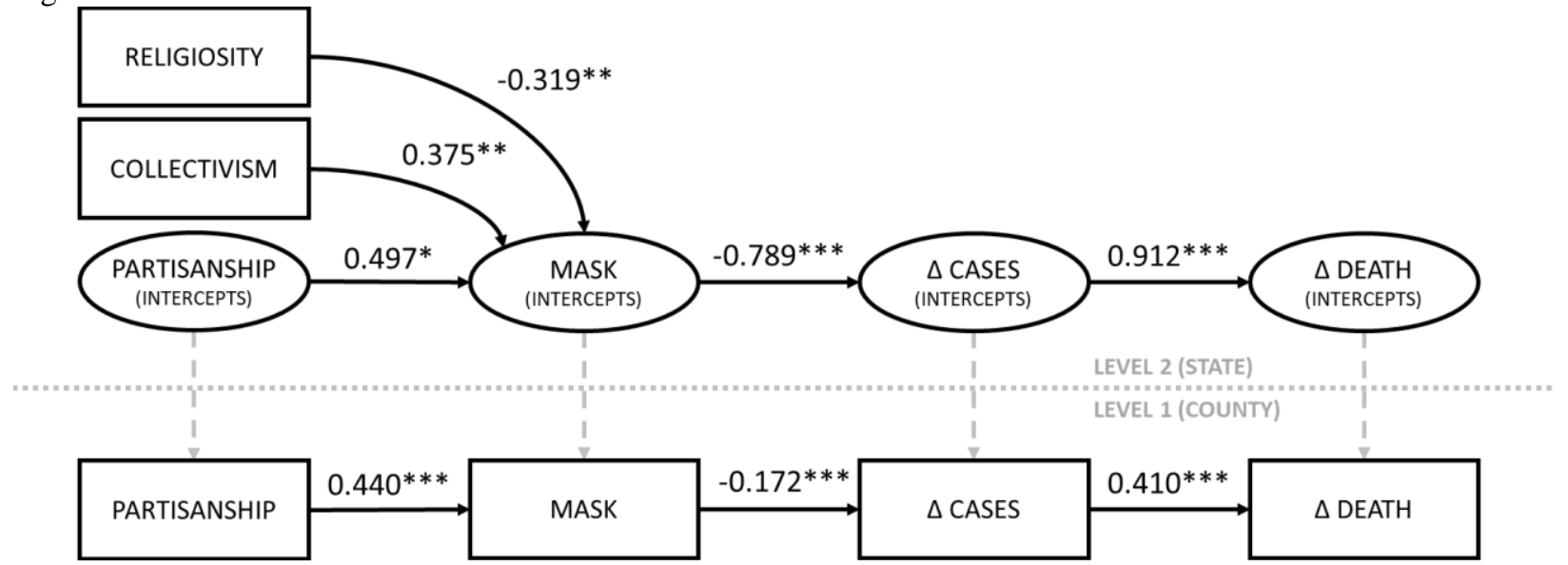

Note: Direct effect paths from partisanship, collectivism, and religiosity to mediating and criterion variables not shown; all coefficients standardized

COVID-19 cases was negatively predicted by mask use ( $\beta$ $=-0.172,95 \%$ CI $[-0.211,-0.133], p<0.001)$ which was in turn positively predicted by partisanship $(\beta=0.440,95 \%$ CI [0.411, 0.469], $p<0.001)$. Accordingly, the relation between partisanship and change in COVID-19 deaths was fully mediated through mask use and change in COVID-19 cases ( $\beta=-0.031,95 \%$ CI $[-0.039,-0.023], p$ $<0.001)$.

The mediating effects were calculated at the state level using latent means intercepts of partisanship, proportional changes in COVID-19 cases and deaths, as well as state variables of religiosity and collectivism (Model 1; Table 6). Proportional change in COVID-19 deaths was positively predicted by the proportional change in COVID-19 cases $(\beta=0.912,95 \%$ CI $[0.617,1.208], p<$ $0.001)$ which in turn was negatively predicted by mask use $(\beta=-0.789,95 \%$ CI [-1.066, -0.512$], p<0.001)$. Mask use was in turn positively predicted by partisanship ( $\beta=$ $0.497,95 \%$ CI $[0.248,0.746], p<0.001)$ and collectivism $(\beta=0.375,95 \%$ CI $[0.135,0.614], p=0.002)$ but negatively predicted by religiosity $(\beta=-0.319,95 \%$ CI [$0.57,-0.068], p=0.013)$. Accordingly, mask use and proportional change in COVID-19 cases fully mediated the relation between proportional change in COVID-19 deaths and partisanship $(\beta=-0.358,95 \%$ CI $[-0.616,-0.1]$, $p=0.007)$, collectivism $(\beta=-0.27,95 \%$ CI $[-0.485$, $0.054], p=0.014)$, and religiosity $(\beta=0.23,95 \% \mathrm{CI}$ $[0.025,0.434], p=0.028)$. Due to the limited sample size of available states, we ran six additional models each controlling for a single notable correlate of mask use, change in COVID-19 cases, and changes in COVID-19 deaths (Models 2-7). Across all models, the indirect effect of Democrat partisanship on COVID-19 deaths was most robust, followed by collectivism, and lastly by religiosity.

\section{Discussion}

As expected, states with mask mandates reported greater mask wearing than those without any mandates. Even though enforcement of masks (e.g., with citations and fines) remained loose, results indicate that such policies nonetheless yielded positive results in increasing the rate of mask wearing in public. As hypothesized, Democrat partisanship and collectivism were positively related to mask usage while religiosity was negatively related. Mask use was then negatively related to outbreak of COVID-19 cases which in turn led to more deaths. Results generally suggest and support the notion that preventive health measures today may serve as useful cues for inferring the trajectory of viral spread in the longterm. Although the study itself relied primarily on crosssectional data, proportional changes in cases and deaths across two time points provide some clue into longitudinal effects.

This is best depicted visually in Figure 4. Population proportional increases in COVID-19 cases and deaths, from July 14 to December 14 show a much larger exponential increase among counties with majority Republican voters compared to their Democrat counterparts. Although both Republican and Democrat counties largely failed to control the viral spread of the virus during Fall 2020, Republican counties quickly overtook Democrat counties during October and November 2020. Whether partisan differences in mask use definitively caused this divide in viral spread trajectory remains to be tested. However, the growing evidence pointing to political ideologies driving behaviors amid a global pandemic (Bruine de Bruin et al., 2020; Gollwitzer et al., 2020; Grossman et al., 2020; Im et al., 2020; Simonov et al., 2020) lend credence to the notion. 
Table 6. Serial Mediation Analyses Controlling for Relevant Demographics

\begin{tabular}{|c|c|c|c|c|c|c|c|c|c|}
\hline \multirow[b]{2}{*}{$\mathbf{X}$} & \multirow{2}{*}{$\begin{array}{l}\mathbf{a} \\
\boldsymbol{\beta}\end{array}$} & \multirow[b]{2}{*}{ M1 } & \multirow{2}{*}{$\begin{array}{l}\mathbf{b} \\
\boldsymbol{\beta}\end{array}$} & \multirow[b]{2}{*}{ M2 } & \multirow{2}{*}{$\begin{array}{l}\text { c } \\
\beta\end{array}$} & \multirow[b]{2}{*}{$\mathbf{Y}$} & \multirow{2}{*}{$\begin{array}{l}\text { d } \\
\boldsymbol{\beta}\end{array}$} & \multicolumn{2}{|c|}{ Indirect Effect } \\
\hline & & & & & & & & $\boldsymbol{\beta}$ & $(95 \% \mathrm{CI})$ \\
\hline \multicolumn{10}{|l|}{ Model 1} \\
\hline Democrat & $0.497 * * *$ & Mask & $-0.789 * * *$ & Cases & $0.912 * * *$ & Deaths & 0.201 & $-0.358 * *$ & $(-0.616,-0.100)$ \\
\hline Collectivism & $0.375^{* *}$ & - & - & - & - & - & 0.066 & $-0.270^{*}$ & $(-0.485,-0.054)$ \\
\hline Religiosity & $-0.319^{*}$ & - & - & - & - & - & 0.219 & $0.230 *$ & $(0.025,0.434)$ \\
\hline \multicolumn{10}{|l|}{ Model 2} \\
\hline Democrat & $0.496^{* * *}$ & Mask & $-0.787 * * *$ & Cases & $0.882 * * *$ & Deaths & 0.181 & $-0.344 * *$ & $(-0.596,-0.091)$ \\
\hline Collectivism & $0.353 *$ & - & - & - & - & - & 0.218 & $-0.245 \dagger$ & $(-0.507,0.018)$ \\
\hline Religiosity & $-0.321 *$ & - & - & - & - & - & 0.220 & $0.222 *$ & $(0.021,0.424)$ \\
\hline \multicolumn{10}{|l|}{ Model 3} \\
\hline Democrat & $0.510 * * *$ & Mask & $-0.786^{* * *}$ & Cases & $0.993 * * *$ & Deaths & $0.319 *$ & $-0.397 * *$ & $(-0.686,-0.109)$ \\
\hline Collectivism & $0.364 * *$ & - & - & - & - & - & -0.033 & $-0.284 *$ & $(-0.525,-0.043)$ \\
\hline Religiosity & $-0.332 *$ & - & - & - & - & - & 0.051 & $0.259 *$ & $(0.022,0.495)$ \\
\hline \multicolumn{10}{|l|}{ Model 4} \\
\hline Democrat & $0.427 * *$ & Mask & $-0.761 * * *$ & Cases & $0.989 * * *$ & Deaths & 0.041 & $-0.321 *$ & $(-0.600,-0.042)$ \\
\hline Collectivism & $0.366^{* *}$ & - & - & - & - & - & 0.060 & $-0.276^{*}$ & $(-0.497,-0.054)$ \\
\hline Religiosity & $-0.390^{*}$ & - & - & - & - & - & 0.013 & $0.293 *$ & $(0.039,0.548)$ \\
\hline \multicolumn{10}{|l|}{ Model 5} \\
\hline Democrat & $0.513 * * *$ & Mask & $-0.655 * * *$ & Cases & $0.965 * * *$ & Deaths & 0.201 & $-0.324 * *$ & $(-0.567,-0.082)$ \\
\hline Collectivism & $0.320 * *$ & - & - & - & - & - & 0.063 & $-0.202 *$ & $(-0.394,-0.01)$ \\
\hline Religiosity & -0.170 & - & - & - & - & - & 0.257 & 0.107 & $(-0.088,0.303)$ \\
\hline \multicolumn{10}{|l|}{ Model 6} \\
\hline Democrat & $0.350^{*}$ & Mask & $-0.812 * * *$ & Cases & $0.915 * * *$ & Deaths & 0.227 & $-0.260^{*}$ & $(-0.517,-0.003)$ \\
\hline Collectivism & $0.389 * *$ & - & - & - & - & - & 0.066 & $-0.289 *$ & $(-0.509,-0.068)$ \\
\hline Religiosity & $-0.397 * *$ & - & - & - & - & - & 0.237 & $0.295^{*}$ & $(0.065,0.525)$ \\
\hline \multicolumn{10}{|l|}{ Model 7} \\
\hline Democrat & $0.502 * * *$ & Mask & $-0.887 * * *$ & Cases & $0.900 * * *$ & Deaths & 0.241 & $-0.401 * *$ & $(-0.673,-0.129)$ \\
\hline Collectivism & $0.247 *$ & - & - & - & - & - & 0.068 & $-0.197 *$ & $(-0.387,-0.008)$ \\
\hline Religiosity & $-0.176 \dagger$ & - & - & - & - & - & 0.225 & 0.140 & $(-0.036,0.317)$ \\
\hline
\end{tabular}

Note: $\dagger p<0.10, * p<0.05, * * p<0.01, * * * p<0.001$; Model 1 = no control variables; Model 2 = controlling for older adult population; Model 3 = controlling for education attainment; Model $4=$ controlling for income inequality; Model 5 = controlling for religious adherents; Model $6=$ controlling for COVID-19 proportion of deaths; Model 7 = controlling for state mask mandate.

\section{General Discussion}

As evidenced from our findings across two studies at the individual-, county-, and state-level, political orientation and partisanship remain key antecedents of mask use, even after controlling for all relevant demographic and socioeconomic variables. This is well within the lines of the partisan rhetoric being pushed forth by each dominant party, where Republicans seem less receptive to preventive health behaviors and see the pandemic as less threatening and more overblown than their Democrat counterparts (Bacon, 2020; Plohl \& Musil, 2020). As long as mask wearing continues to reign as a key vehicle for partisan ideology, the polarized political landscape presents itself as an inhospitable environment for the dissemination and transmission of objective scientific facts. If findings from less contested times are evidence of anything, prior studies on the influence of political partisanship and ideology paint a grim picture heading into the remainder of COVID-19 pandemic; one's political party membership may override any individual preferences in policy (Cohen, 2003) and political contingents may be quick to denounce efforts pushed forth from proponents of the opposing party (Levendusky, 2013). Such instances can continue to create partisan echo chambers (Van Bavel et al., 2020; Van Bavel \& Pereira, 2018), further strengthening and legitimizing an otherwise scientifically unsupported claim (Druckman et al., 2013). As partisan followers may look to political leaders and pundits as sources of trustworthy information, it is increasingly becoming more important for the accurate dissemination of scientific facts over less grounded opinions, lest the widespread efficacy of mask adherence suffer incommensurate with the polarized divide in the political system.

Cultural collectivism was another large positive correlate of mask adherence. This finding is generally congruent with prior empirical evidence of the role of 
Figure 4. Proportional Increases in COVID-19 Cases and Deaths by Partisanship

(A) Proportional Cases of COVID-19

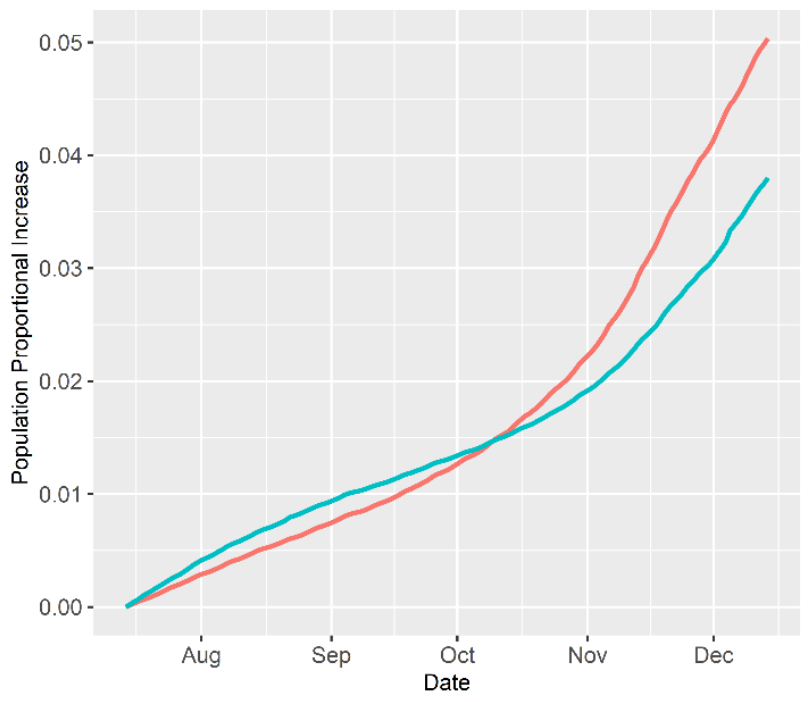

(B) Proportional Deaths from COVID-19

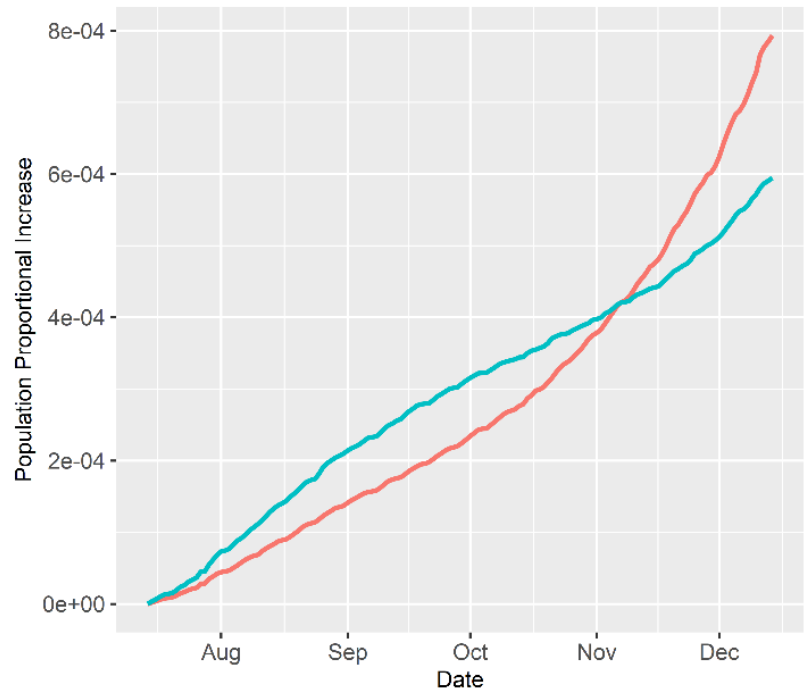

Partisanship - Republican - Democrat

Note: Figures A-B show increases in COVID-19 cases and deaths from July 14 to December 14, 2020; Population proportional cases and deaths normalized at zero on July 14.

collectivism in preventive health behaviors (Biddlestone et al., 2020) and physical distancing (Im et al., 2020; Im $\&$ Chen, 2020). As previously discussed in the introduction, this finding is not entirely surprising; East Asian cultures have long been known for high mask adherence among its populace even before the spread of the COVID-19 pandemic. While not examined in this study, it remains largely plausible that this strong, positive effect is driven by one's sense of social responsibility to protect not only their immediate ingroup, but also the general collective. Indeed, as a sense of social responsibility was positively related to greater engagement in behaviors that benefited the mass (Oosterhoff et al., 2020; Oosterhoff \& Palmer, 2020), future studies may examine the potential mediating motivators related to social responsibility that explain the connection between collectivism orientation and preventive health behaviors amidst the pandemic.

Lastly, religiosity was a moderate negative correlate of mask use. Although not as consistent or robust as partisanship or collectivism while controlling for relevant constructs, the results of this study generally parallel recent research findings (DeFranza et al., 2020; Jaja et al., 2020; Perry et al., 2020; Vermeer \& Kregting, 2020) as well as anecdotal accounts of defiance among ardent religious bodies (BBC, 2020; Noyes, 2020; Shin, 2020). To the extent that policies are viewed as restricting one's religious freedom, opposition may remain a rampant issue (DeFranza et al., 2020; Jaja et al., 2020). However, it remains necessary to also conduct further research in efforts to better separate religious zealotry from Christian nationalism. Perry et al. (2020) found that aspects of Christian nationalism, many of which coincide with conservative parties, were the driving factors rather than religiosity itself. In our current study, it is unclear whether respondents answered the religiosity measure from Gallup with Christian nationalism in mind in the absence of an alternative method of doing so. Many religious groups and centers have been compliant in adhering to government issued health regulations, readily moving religious services to virtual settings and staging food drives to assist the needy (Wildman et al., 2020). Thus, future research may better separate the extent to which religious moderates may systematically differ from zealots.

\section{Limitations \& Future Directions}

Although this paper examined changes in COVID-19 cases and deaths, the pseudo-Granger causality approach inhibits the ability to make strong inferences about the temporal relations between mask use and downstream effects on COVID-19 outcomes. Future research may benefit from utilizing intensive longitudinal approaches (e.g., time-series analyses) as data allows to investigate the benefits of widespread mask use. Additionally, the current paper only examined mask use in the US. Future research may examine cross-cultural robustness of these results. Lastly, as was the case for many East Asian countries after experiencing numerous recent outbreaks of diseases (e.g., SARS, MERS) and meteorological phenomena (e.g., Yellow dust), future research is 
necessary to examine whether extensive use of masks in the US will subsequently encourage mask use in the future against less serious issues, such as influenza.

\section{Conclusion}

Social values continue to play a pivotal role in the fight against COVID-19. This study highlights that partisanship, individualism-collectivism, and religiosity appear to be the largest correlates to mask use in the US. While mask use alone cannot curb the spread of COVID19 , utilizing masks in conjunction with other preventive health behaviors (e.g., social distancing, frequent handwashing) and vaccines can prove vital in significantly controlling viral spread for the future. Future studies should aim to examine how social interventions may specifically appeal to these values in increasing mask adherence.

\section{Acknowledgements}

County-level mask use data courtesy of The New York Times and Dynata. Individual-level mask use data courtesy of the Understanding America Study collected by the University of Southern California. All analyses and interpretations involving these data are the authors' own and were made independent of The New York Times, Dynata, and the University of Southern California.

\section{Disclosure of Conflict}

The authors declare no conflict of interest.

\section{References}

Adolph, C., Amano, K., Bang-Jensen, B., Fullman, N., Magistro, B. Reinke, G., \& Wilkerson, J. (2020). Governor partisanship explains the adoption of statewide mandates to wear face coverings. MedRxiv, 2020.08.31.20185371. https://doi.org/10.1101/2020.08.31.20185371

Allcott, H., Boxell, L., Conway, J., Gentzkow, M., Thaler, M., \& Yang, D. Y. (2020). Polarization and Public Health: Partisan Differences in Social Distancing During the Coronavirus Pandemic (SSRN Scholarly Paper ID 3574415). Social Science Research Network. https://papers.ssrn.com/abstract=3574415

Bacon, P. (2020, April 3). Are Democrats And Republicans Reacting Differently To Coronavirus? It Depends What You're Asking Them. FiveThirtyEight. https://fivethirtyeight.com/features/are-democratsand-republicans-reacting-differently-to-coronavirus-it-dependswhat-youre-asking-them/

BBC. (2020, August 17). New church coronavirus cluster alarms South Korea. BBC News. https://www.bbc.com/news/world-asia-53803011

Bellas, P. A., Asch, S. M., \& Wilkes, M. (2000). What students bring to medical school: Attitudes toward health promotion and prevention American Journal of Preventive Medicine, 18(3), 242-248. https://doi.org/10.1016/S0749-3797(99)00164-6

Biddlestone, M., Green, R., \& Douglas, K. (2020). Cultural orientation, powerlessness, belief in conspiracy theories, and intentions to reduce the spread of COVID-19. British Journal of Social Psychology, Ahead-of-print(Ahead-of-print). https://kar.kent.ac.uk/81621/
Borg, M. A. (2014). Cultural determinants of infection control behaviour: Understanding drivers and implementing effective change. Journal of Hospital Infection, 86(3), 161-168. https://doi.org/10.1016/j.jhin.2013.12.006

Bosman, J. (2020, July 29). Amid Virus Surge, Republicans Abruptly Urge Masks Despite Trump's Resistance. The New York Times. https://www.nytimes.com/2020/07/01/us/coronavirus-masks.html

Bruine de Bruin, W., Saw, H.-W., \& Goldman, D. P. (2020). Political polarization in US residents' COVID-19 risk perceptions, policy preferences, and protective behaviors. Journal of Risk and Uncertainty, 61(2), 177-194. https://doi.org/10.1007/s11166-02009336-3

CDC. (2020, February 11). Coronavirus Disease 2019 (COVID-19). Centers for Disease Control and Prevention. https://www.cdc.gov/coronavirus/2019-ncov/prevent-gettingsick/cloth-face-cover-guidance.html

CDC. (2021, February 23). COVID-19 and Your Health. Centers for Disease Control and Prevention. https://www.cdc.gov/coronavirus/2019-ncov/transmission/variantcases.html

Cheng, V. C. C., Wong, S. C., Chuang, V. W. M., So, S. Y. C., Chen, J. H. K., Sridhar, S., To, K. K. W., Chan, J. F. W., Hung, I. F. N., Ho, P. L., \& Yuen, K. Y. (2020). The role of community-wide wearing of face mask for control of coronavirus disease 2019 (COVID-19) epidemic due to SARS-CoV-2. Journal of Infection, 81(1), 107-114. https://doi.org/10.1016/j.jinf.2020.04.024

CIVIQS. (2020). Coronavirus: Outbreak concern. https://civiqs.com/results/coronavirus_concern?uncertainty=true\&an notations $=$ true $\&$ zoomIn $=$ true

Cohen, G. L. (2003). Party Over Policy: The Dominating Impact of Group Influence on Political Beliefs. Journal of Personality and Social Psychology, 85(5), 808-822. https://doi.org/10.1037/00223514.85.5.808

County Health Rankings. (2020). 2020 State Reports. Robert Wood Johnson Foundation. https://www.countyhealthrankings.org/reports/state-reports

DeFranza, D., Lindow, M., Harrison, K., Mishra, A., \& Mishra, H. (2020). Religion and reactance to COVID-19 mitigation guidelines. American Psychologist, Online ahead of print. https://doi.org/10.1037/amp0000717

Druckman, J. N., Peterson, E., \& Slothuus, R. (2013). How Elite Partisan Polarization Affects Public Opinion Formation. American Political Science Review, 107(1), 57-79. https://doi.org/10.1017/S0003055412000500

Edsall, T. B. (2020, May 20). Opinion | When the Mask You're Wearing 'Tastes Like Socialism.' The New York Times. https://www.nytimes.com/2020/05/20/opinion/coronavirus-trumppartisanship.html

Eikenberry, S. E., Mancuso, M., Iboi, E., Phan, T., Eikenberry, K., Kuang, Y., Kostelich, E., \& Gumel, A. B. (2020). To mask or not to mask: Modeling the potential for face mask use by the general public to curtail the COVID-19 pandemic. Infectious Disease Modelling, 5, 293-308. https://doi.org/10.1016/j.idm.2020.04.001

Everett, J. A. C., Colombatto, C., Chituc, V., Brady, W. J., \& Crockett, M. (2020). The effectiveness of moral messages on public health behavioral intentions during the COVID-19 pandemic [Preprint]. PsyArXiv. https://doi.org/10.31234/osf.io/9yqs8

Fieldstadt, E. (2020). Ohio lawmaker refuses to wear mask because he says it dishonors God. NBC News. https://www.nbcnews.com/news/us-news/ohio-lawmaker-refuseswear-mask-because-he-says-it-dishonors-n1201106

Galloway, S. E. (2021). Emergence of SARS-CoV-2 B.1.1.7 LineageUnited States, December 29, 2020-January 12, 2021. MMWR. Morbidity and Mortality Weekly Report, 70. https://doi.org/10.15585/mmwr.mm7003e2

Gallup. (2017). State of the States. Gallup.Com. https://news.gallup.com/poll/125066/State-States.aspx

Gallup. (2020, April 9). Amid Pandemic, News Attention Spikes; Media Favorability Flat. Gallup.Com. 
https://news.gallup.com/opinion/gallup/307934/amid-pandemicnews-attention-spikes-media-favorability-flat.aspx

Gaygısız, Ü., Lajunen, T., \& Gaygisız, E. (2017). Socio-economic factors, cultural values, national personality and antibiotics use: A cross-cultural study among European countries. Journal of Infection and Public Health, 10(6), 755-760. https://doi.org/10.1016/j.jiph.2016.11.011

Gollwitzer, A., Martel, C., Brady, W. J., Pärnamets, P., Freedman, I. G., Knowles, E. D., \& Van Bavel, J. J. (2020). Partisan differences in physical distancing are linked to health outcomes during the COVID19 pandemic. Nature Human Behaviour, 4(11), 1186-1197. https://doi.org/10.1038/s41562-020-00977-7

Grammich, C., Hadaway, K., Houseal, R., Jones, D., Krindatch, A., Stanley, R., \& Taylor, R. (2018). U.S. Religion Census Religious Congregations and Membership Study, 2010 (County File). https://doi.org/10.17605/OSF.IO/QUN29

Grossman, G., Kim, S., Rexer, J., \& Thirumurthy, H. (2020). Political Partisanship Influences Behavioral Responses to Governors Recommendations for COVID-19 Prevention in the United States (SSRN Scholarly Paper ID 3578695). Social Science Research Network. https://doi.org/10.2139/ssrn.3578695

Hofstede, G., Hofstede, G. J., \& Minkov, M. (2010). Cultures and Organizations: Software of the Mind, Third Edition. McGraw Hill Professional.

Hsiehchen, D., Espinoza, M., \& Slovic, P. (2020). Political partisanship and mobility restriction during the COVID-19 pandemic. Public Health, 187, 111-114. https://doi.org/10.1016/j.puhe.2020.08.009

Huynh, T. L. D. (2020). Does culture matter social distancing under the COVID-19 pandemic? Safety Science, 130, 104872 https://doi.org/10.1016/j.ssci.2020.104872

Im, H., Ahn, C., Wang, P., \& Chen, C. (2020). An Early Examination: Psychological, Health, and Economic Correlates and Determinants of Social Distancing Amidst COVID-19 [Preprint]. PsyArXiv. https://doi.org/10.31234/osf.io/9ravu

Im, H., \& Chen, C. (2020). Social Distancing Around the Globe: Cultural Correlates of Reduced Mobility [Preprint]. PsyArXiv. https://doi.org/10.31234/osf.io/b2s37

Jackson, E. S., Tucker, C. M., \& Herman, K. C. (2007). Health Value, Perceived Social Support, and Health Self-Efficacy as Factors in a Health-Promoting Lifestyle. Journal of American College Health, 56(1), 69-74. https://doi.org/10.3200/JACH.56.1.69-74

Jaja, I. F., Anyanwu, M. U., \& Jaja, C.-J. I. (2020). Social distancing How religion, culture and burial ceremony undermine the effort to curb COVID-19 in South Africa. Emerging Microbes \& Infections, 9(1), 1077-1079. https://doi.org/10.1080/22221751.2020.1769501

Jay, J., Bor, J., Nsoesie, E. O., Lipson, S. K., Jones, D. K., Galea, S., \& Raifman, J. (2020). Neighbourhood income and physical distancing during the COVID-19 pandemic in the United States. Nature Human Behaviour, 4(12), 1294-1302. https://doi.org/10.1038/s41562-02000998-2

Johns Hopkins Coronavirus Resource Center. (2020). Coronavirus Resource Center. COVID-19 Case Tracker. https://coronavirus.jhu.edu/

Kannan, V. D., \& Veazie, P. J. (2018). Political orientation, political environment, and health behaviors in the United States. Preventive Medicine, 114, 95-101. https://doi.org/10.1016/j.ypmed.2018.06.011

Katz, J., Sanger-Katz, M., \& Quealy, K. (2020, July 17). A Detailed Map of Who Is Wearing Masks in the U.S. The New York Times. https://www.nytimes.com/interactive/2020/07/17/upshot/coronaviru s-face-mask-map.html

Kavanagh, N. M., Goel, R. R., \& Venkataramani, A. S. (2020). Association of County-Level Socioeconomic and Political Characteristics with Engagement in Social Distancing for COVID-19 [Preprint]. Health https://doi.org/10.1101/2020.04.06.20055632

Kim, K.-B., Kim, H.-A., \& Sok, S.-H. R. (2008). A Study on Health Perception, Health Knowledge, and Health Promoting Behavior in the Elderly. Journal of East-West Nursing Research, 14(1), 56-67.

Kushner Gadarian, S., Goodman, S. W., \& Pepinsky, T. B. (2020). Partisanship, Health Behavior, and Policy Attitudes in the Early
Stages of the COVID-19 Pandemic (SSRN Scholarly Paper ID 3562796). Social Science Research Network. https://doi.org/10.2139/ssrn.3562796

Levendusky, M. (2013). Partisan Media Exposure and Attitudes Toward the Opposition. Political Communication, 30(4), 565-581. https://doi.org/10.1080/10584609.2012.737435

Liang, M., Gao, L., Cheng, C., Zhou, Q., Uy, J. P., Heiner, K., \& Sun, C. (2020). Efficacy of face mask in preventing respiratory virus transmission: A systematic review and meta-analysis. Travel Med Infect Dis, 101751. https://doi.org/10.1016/j.tmaid.2020.101751

Liu, X., \& Zhang, S. (2020). COVID-19: Face masks and human-tohuman transmission. Influenza Other Respir Viruses, 14(4), 472-473. https://doi.org/10.1111/irv.12740

Markowitz, A. (2020, October 1). Does Your State Have a Mask Mandate Due to Coronavirus? AARP. http://www.aarp.org/health/healthy-living/info-2020/states-maskmandates-coronavirus.html

McKelvey, T. (2020, July 20). Why are Americans so angry about masks? BBC News. https://www.bbc.com/news/world-us-canada-53477121

Noyes, D. (2020, September 8). South Bay church holds indoor services as COVID-19 fines reach $\$ 100 \mathrm{~K}$, criminal charge possible. ABC7 San Francisco. https://abc7news.com/6413383/

Oosterhoff, B., \& Palmer, C. (2020). Psychological Correlates of News Monitoring, Social Distancing, Disinfecting, and Hoarding Behaviors among US Adolescents during the COVID-19 Pandemic [Preprint]. PsyArXiv. https://doi.org/10.31234/osf.io/rpcy4

Oosterhoff, B., palmer, C., Wilson, J., \& Shook, N. (2020). Adolescents' Motivations to Engage in Social Distancing during the COVID-19 Pandemic: Associations with Mental and Social Health [Preprint]. PsyArXiv. https://doi.org/10.31234/osf.io/jd2kq

Payne, B. K., Brown-Iannuzzi, J. L., \& Hannay, J. W. (2017). Economic inequality increases risk taking. Proceedings of the National Academy of Sciences, 114(18), 4643-4648. https://doi.org/10.1073/pnas.1616453114

Perry, S. L., Whitehead, A. L., \& Grubbs, J. B. (2020). Culture Wars and COVID-19 Conduct: Christian Nationalism, Religiosity, and Americans' Behavior During the Coronavirus Pandemic. Journal for the Scientific Study of Religion, 59(3), 405-416. https://doi.org/10.1111/jssr.12677

Pietsch, B., \& Zimmer, C. (2020, December 29). The first confirmed U.S. case of the more contagious British variant has been found in Colorado. The New York Times. https://www.nytimes.com/2020/12/29/world/covid-variant-britishus.html

Plohl, N., \& Musil, B. (2020). Modeling compliance with COVID-19 prevention guidelines: The critical role of trust in science. Psychology, Health \& Medicine, 1-12. https://doi.org/10.1080/13548506.2020.1772988

Rantz, J. (2020, June 29). The conservative argument for coronavirus masks $\quad$ Opinion. Newsweek. https://www.newsweek.com/conservative-argument-coronavirusmasks-opinion-1513977

Shin, H. (2020, September 8). South Korea's defiant churches face backlash for hampering COVID-19 response. Reuters. https://www.reuters.com/article/us-health-coronavirus-southkoreachurch-idUSKBN25Z1MU

Simonov, A., Sacher, S., Dube, J.-P. H., \& Biswas, S. (2020). The Persuasive Effect of Fox News: Non-Compliance with Social Distancing During the COVID-19 Pandemic. SSRN Electronic Journal. https://doi.org/10.2139/ssrn.3604214

Townhall. (2016). Election 2016 Results Map and Key Races for the President elections -View the latest election results, news, polls and conservative election commentary. Townhall. https://townhall.com/election/2016/president/

Triandis, H. C. (2001). Individualism-Collectivism and Personality. $\begin{array}{lll}\text { Journal of Personality, 69(6), 907-924. } & \text { 90 }\end{array}$ https://doi.org/10.1111/1467-6494.696169

U.S. Bureau of Economic Analysis. (2019). Personal Income by County, Metro, and Other Areas | U.S. Bureau of Economic Analysis (BEA). Local Area Personal Income, 2018. 
https://www.bea.gov/data/income-saving/personal-income-countymetro-and-other-areas

U.S. Census Bureau. (2018). Aging Population in the U.S. ACS 2011 2015. The United States Census Bureau https://www.census.gov/data/tables/time-series/demo/age-andsex/aging-pop-acs.html

U.S. Census Bureau. (2019). American Community Survey (ACS). The United States Census Bureau. https://www.census.gov/programssurveys/acs

U.S. Census Bureau. (2020). County Population Totals: 2010-2019. The United States Census Bureau https://www.census.gov/data/datasets/timeseries/demo/popest/2010s-counties-total.html

U.S. Department of Agriculture. (2020). USDA ERS - County-level Data Sets. Education. https://www.ers.usda.gov/data-products/countylevel-data-sets/

USA Facts. (2021, January 30). US Coronavirus Cases and Deaths. USAFacts.Org. /visualizations/coronavirus-covid-19-spread-map

Van Bavel, J., Baicker, K., Boggio, P. S., Capraro, V., Cichocka, A., Cikara, M., Crockett, M. J., Crum, A. J., Douglas, K. M., Druckman, J. N., Drury, J., Dube, O., Ellemers, N., Finkel, E. J., Fowler, J. H., Gelfand, M., Han, S., Haslam, S. A., Jetten, J., ... Willer, R. (2020). Using social and behavioural science to support COVID-19 pandemic response. Nature Human Behaviour, 4(5), 460-471. https://doi.org/10.1038/s41562-020-0884-z

Van Bavel, J., \& Pereira, A. (2018). The Partisan Brain: An IdentityBased Model of Political Belief. Trends in Cognitive Sciences, 22(3), 213-224. https://doi.org/10.1016/j.tics.2018.01.004
Vandello, J. A., \& Cohen, D. (1999). Patterns of individualism and collectivism across the United States. Journal of Personality and Social Psychology, 77(2), 279-292. https://doi.org/10.1037/00223514.77.2.279

Vermeer, P., \& Kregting, J. (2020). Religion and the Transmission of COVID-19 in The Netherlands. Religions, 11(8), 393. https://doi.org/10.3390/rel11080393

Watson, I., \& Oancea, S. C. (2020). Does self-rated health status influence receipt of an annual flu vaccination? Preventive Medicine, 131, 105949. https://doi.org/10.1016/j.ypmed.2019.105949

Weaver, K. E., Palmer, N., Lu, L., Case, L. D., \& Geiger, A. M. (2013). Rural-urban differences in health behaviors and implications for health status among US cancer survivors. Cancer Causes \& Control, 24(8), 1481-1490. https://doi.org/10.1007/s10552-013-0225-x

Weiss, B. D., \& Paasche-Orlow, M. K. (2020). Disparities in Adherence to COVID-19 Public Health Recommendations. HLRP: Health Literacy Research and Practice, 4(3), e171-e173. https://doi.org/10.3928/24748307-20200723-01

Wildman, W. J., Bulbulia, J., Sosis, R., \& Schjoedt, U. (2020). Religion and the COVID-19 pandemic. Religion, Brain \& Behavior, 10(2), 115-117. https://doi.org/10.1080/2153599X.2020.1749339

Wong, B. (2020, September 18). Why East Asian Countries Were Wearing Masks Long Before COVID-19. HuffPost. https://www.huffpost.com/entry/east-asian-countries-face-masksbefore-covid_1_5f63a43fc5b61845586837f4 


\section{Appendix}

Table A. Multilevel Logistic Regression Odds Ratios for Mask Adherence (Political Orientation)

\begin{tabular}{|c|c|c|c|c|}
\hline \multirow[b]{2}{*}{ Predictors } & \multicolumn{2}{|l|}{ Model 1} & \multicolumn{2}{|l|}{ Model 5} \\
\hline & Odds Ratios & CI & Odds Ratios & CI \\
\hline Intercept & $4.828 * * *$ & $3.633-6.416$ & $5.431 * * *$ & $4.058-7.267$ \\
\hline Health & 1.061 & $0.963-1.168$ & 1.089 & $0.982-1.207$ \\
\hline Gender & $0.785 *$ & $0.651-0.947$ & 0.877 & $0.719-1.070$ \\
\hline Education & 1.104 & $0.991-1.230$ & 1.112 & $0.992-1.246$ \\
\hline Working Status & 1.143 & $0.920-1.421$ & 1.144 & $0.910-1.439$ \\
\hline Household Income & 1.097 & $0.973-1.235$ & 1.115 & $0.983-1.264$ \\
\hline Age & $1.442 * * *$ & $1.292-1.609$ & $1.354 * * *$ & $1.205-1.521$ \\
\hline Hispanic/Latino & $1.511 *$ & $1.026-2.226$ & 1.247 & $0.828-1.878$ \\
\hline Black & $1.894 * *$ & $1.215-2.952$ & $1.702 *$ & $1.059-2.734$ \\
\hline Native American & 0.864 & $0.562-1.328$ & 0.879 & $0.557-1.388$ \\
\hline Asian & 1.059 & $0.660-1.701$ & 0.859 & $0.524-1.408$ \\
\hline Pacific Islander & 0.982 & $0.415-2.322$ & 0.987 & $0.397-2.454$ \\
\hline Conservatism & $0.636 * * *$ & $0.574-0.705$ & $0.724 * * *$ & $0.648-0.809$ \\
\hline Mask Efficiency & & & $1.492 * * *$ & $1.359-1.637$ \\
\hline COVID Hazard & & & 1.017 & $0.917-1.127$ \\
\hline COVID Safety & & & $1.294 * * *$ & $1.166-1.435$ \\
\hline \multicolumn{5}{|l|}{ Random Effects } \\
\hline$\sigma 2$ & 3.29 & & 3.29 & \\
\hline$\tau 00_{\text {state }}$ & 0.50 & & 0.49 & \\
\hline ICC & 0.13 & & 0.13 & \\
\hline $\mathrm{N}_{\text {state }}$ & 51 & & 51 & \\
\hline Observations & 4202 & & 4042 & \\
\hline Marginal $\mathrm{R}^{2}$ / Conditional $\mathrm{R}^{2}$ & $0.085 / 0.205$ & & $0.135 / 0.248$ & \\
\hline
\end{tabular}

Note: ${ }^{*} p<0.05, * * p<0.01, * * * p<0.001$. 
Table B. Multilevel Logistic Regression Odds Ratios for Mask Adherence (Partisanship)

\begin{tabular}{|c|c|c|c|c|}
\hline \multirow[b]{2}{*}{ Predictors } & \multicolumn{2}{|l|}{ Model 1} & \multicolumn{2}{|l|}{ Model 5} \\
\hline & Odds Ratios & CI & Odds Ratios & CI \\
\hline Intercept & $4.162 * * *$ & $3.076-5.631$ & $4.937 * * *$ & $3.611-6.750$ \\
\hline Health & 1.03 & $0.950-1.117$ & 1.057 & $0.969-1.153$ \\
\hline Gender & $0.770 * *$ & $0.653-0.909$ & 0.84 & $0.704-1.003$ \\
\hline Education & $1.116 *$ & $1.017-1.225$ & $1.134 *$ & $1.027-1.252$ \\
\hline Working Status & 1.115 & $0.923-1.348$ & 1.141 & $0.932-1.396$ \\
\hline Household Income & 1.098 & $0.994-1.212$ & $1.123 *$ & $1.010-1.249$ \\
\hline Age & $1.388 * * *$ & $1.261-1.528$ & $1.361 * * *$ & $1.228-1.508$ \\
\hline Hispanic/Latino & 1.334 & $0.964-1.846$ & 1.188 & $0.836-1.689$ \\
\hline Black & $1.551 *$ & $1.098-2.190$ & $1.497 *$ & $1.028-2.179$ \\
\hline Native American & 0.955 & $0.657-1.387$ & 1.032 & $0.689-1.545$ \\
\hline Asian & 1.125 & $0.723-1.751$ & 0.912 & $0.577-1.444$ \\
\hline Pacific Islander & 0.961 & $0.472-1.954$ & 1.033 & $0.478-2.234$ \\
\hline Democrat & $1.749 * * *$ & $1.396-2.191$ & $1.398 * *$ & $1.100-1.779$ \\
\hline Republican & $0.759 * *$ & $0.621-0.927$ & $0.787 *$ & $0.634-0.976$ \\
\hline Mask Efficiency & & & $1.423 * * *$ & $1.312-1.543$ \\
\hline COVID Hazard & & & 1.050 & $0.959-1.149$ \\
\hline COVID Safety & & & $1.289 * * *$ & $1.178-1.410$ \\
\hline \multicolumn{5}{|l|}{ Random Effects } \\
\hline$\sigma 2$ & 3.29 & & 3.29 & \\
\hline$\tau 00_{\text {state }}$ & 0.52 & & 0.51 & \\
\hline ICC & 0.14 & & 0.14 & \\
\hline $\mathrm{N}_{\text {state }}$ & 51 & & 51 & \\
\hline Observations & 5154 & & 4905 & \\
\hline Marginal $\mathrm{R}^{2}$ / Conditional $\mathrm{R}^{2}$ & $0.072 / 0.198$ & & $0.119 / 0.238$ & \\
\hline
\end{tabular}

Note: ${ }^{*} p<0.05, * * p<0.01, * * * p<0.001$. 
Table C. Multilevel Regression Model for Partisan Membership

\begin{tabular}{|c|c|c|c|c|c|}
\hline & $\begin{array}{l}\text { Model } 1 \\
\text { (Mask) }\end{array}$ & $\begin{array}{l}\text { Model } 2 \\
\text { (Mask Eff) }\end{array}$ & $\begin{array}{l}\text { Model 3 } \\
\text { (COVID \%) }\end{array}$ & $\begin{array}{l}\text { Model } 4 \\
\text { (Contagion) }\end{array}$ & $\begin{array}{l}\text { Model 5 } \\
\text { (Mask) }\end{array}$ \\
\hline Predictors & $\beta(95 \% \mathrm{CI})$ & $\beta(95 \%$ CI $)$ & $\beta(95 \%$ CI $)$ & $\beta(95 \% \mathrm{CI})$ & $\beta(95 \%$ CI $)$ \\
\hline Intercept & $\begin{array}{l}1.603 * * * \\
(1.364-1.842)\end{array}$ & $\begin{array}{l}-0.018 \\
(-0.057-0.021)\end{array}$ & $\begin{array}{l}0.036 \\
(-0.001-0.073)\end{array}$ & $\begin{array}{l}0.000 \\
(-0.039-0.038)\end{array}$ & $\begin{array}{l}1.722 * * * \\
(1.479-1.965)\end{array}$ \\
\hline Health & $\begin{array}{l}0.029 \\
(-0.051-0.110)\end{array}$ & $\begin{array}{l}0.022 \\
(-0.007-0.050)\end{array}$ & $\begin{array}{l}-0.118 * * * \\
(-0.145--0.090)\end{array}$ & $\begin{array}{l}-0.062 * * * \\
(-0.089--0.035)\end{array}$ & $\begin{array}{l}0.055 \\
(-0.031-0.140)\end{array}$ \\
\hline Gender & $\begin{array}{l}-0.129 * * \\
(-0.211--0.047)\end{array}$ & $\begin{array}{l}-0.104 * * * \\
(-0.132--0.076)\end{array}$ & $\begin{array}{l}-0.065 * * * \\
(-0.092--0.038)\end{array}$ & $\begin{array}{l}-0.071 * * * \\
(-0.098--0.045)\end{array}$ & $\begin{array}{l}-0.086 \\
(-0.174-0.002)\end{array}$ \\
\hline Education & $\begin{array}{l}0.110 * \\
(0.017-0.202)\end{array}$ & $\begin{array}{l}0.010 \\
(-0.021-0.041)\end{array}$ & $\begin{array}{l}-0.008 \\
(-0.038-0.023)\end{array}$ & $\begin{array}{l}-0.067 * * * \\
(-0.097--0.038)\end{array}$ & $\begin{array}{l}0.125 * \\
(0.026-0.223)\end{array}$ \\
\hline Working Status & $\begin{array}{l}0.054 \\
(-0.040-0.148)\end{array}$ & $\begin{array}{l}0.005 \\
(-0.027-0.037)\end{array}$ & $\begin{array}{l}0.041 * * \\
(0.010-0.073)\end{array}$ & $\begin{array}{l}-0.023 \\
(-0.053-0.007)\end{array}$ & $\begin{array}{l}0.065 \\
(-0.035-0.165)\end{array}$ \\
\hline Household Income & $\begin{array}{l}0.093 \\
(-0.006-0.191)\end{array}$ & $\begin{array}{l}-0.009 \\
(-0.043-0.024)\end{array}$ & $\begin{array}{l}-0.011 \\
(-0.043-0.022)\end{array}$ & $\begin{array}{l}-0.067 * * * \\
(-0.098--0.035)\end{array}$ & $\begin{array}{l}0.115 * \\
(0.010-0.220)\end{array}$ \\
\hline Age & $\begin{array}{l}0.326 * * * \\
(0.231-0.422)\end{array}$ & $\begin{array}{l}0.094 * * * \\
(0.062-0.126)\end{array}$ & $\begin{array}{l}-0.046 * * \\
(-0.077--0.015)\end{array}$ & $\begin{array}{l}0.036 * \\
(0.006-0.067)\end{array}$ & $\begin{array}{l}0.305 * * * \\
(0.203-0.407)\end{array}$ \\
\hline Hispanic/Latino & $\begin{array}{l}0.102 \\
(-0.013-0.216)\end{array}$ & $\begin{array}{l}0.070 * * * \\
(0.038-0.101)\end{array}$ & $\begin{array}{l}0.015 \\
(-0.016-0.046)\end{array}$ & $\begin{array}{l}0.124 * * * \\
(0.094-0.154)\end{array}$ & $\begin{array}{l}0.06 \\
(-0.063-0.183)\end{array}$ \\
\hline Black & $\begin{array}{l}0.127 * \\
(0.027-0.227)\end{array}$ & $\begin{array}{l}0.016 \\
(-0.013-0.045)\end{array}$ & $\begin{array}{l}-0.075 * * * \\
(-0.103--0.046)\end{array}$ & $\begin{array}{l}0.089 * * * \\
(0.061-0.116)\end{array}$ & $\begin{array}{l}0.115 * \\
(0.008-0.223)\end{array}$ \\
\hline Native American & $\begin{array}{l}-0.01 \\
(-0.093-0.073)\end{array}$ & $\begin{array}{l}-0.011 \\
(-0.039-0.017)\end{array}$ & $\begin{array}{l}0.015 \\
(-0.012-0.042)\end{array}$ & $\begin{array}{l}-0.017 \\
(-0.044-0.009)\end{array}$ & $\begin{array}{l}0.007 \\
(-0.082-0.096)\end{array}$ \\
\hline Asian & $\begin{array}{l}0.029 \\
(-0.079-0.136)\end{array}$ & $\begin{array}{l}0.044 * * \\
(0.015-0.073)\end{array}$ & $\begin{array}{l}-0.003 \\
(-0.031-0.026)\end{array}$ & $\begin{array}{l}0.071 * * * \\
(0.043-0.098)\end{array}$ & $\begin{array}{l}-0.022 \\
(-0.135-0.090)\end{array}$ \\
\hline Pacific Islander & $\begin{array}{l}-0.005 \\
(-0.096-0.085)\end{array}$ & $\begin{array}{l}-0.018 \\
(-0.046-0.010)\end{array}$ & $\begin{array}{l}0.004 \\
(-0.024-0.031)\end{array}$ & $\begin{array}{l}-0.006 \\
(-0.033-0.020)\end{array}$ & $\begin{array}{l}0.004 \\
(-0.093-0.101)\end{array}$ \\
\hline Democrat & $\begin{array}{l}0.275 * * * \\
(0.164-0.385)\end{array}$ & $\begin{array}{l}0.107 * * * \\
(0.072-0.142)\end{array}$ & $\begin{array}{l}0.055 * * \\
(0.021-0.090)\end{array}$ & $\begin{array}{l}0.103 * * * \\
(0.070-0.136)\end{array}$ & $\begin{array}{l}0.165 * * \\
(0.047-0.283)\end{array}$ \\
\hline Republican & $\begin{array}{l}-0.131 * * \\
(-0.226--0.036)\end{array}$ & $\begin{array}{l}-0.040 * \\
(-0.075--0.005)\end{array}$ & $\begin{array}{l}-0.062 * * * \\
(-0.096--0.028)\end{array}$ & $\begin{array}{l}-0.099 * * * \\
(-0.132--0.066)\end{array}$ & $\begin{array}{l}-0.114 * \\
(-0.216--0.011)\end{array}$ \\
\hline Mask Effectiveness & & & & & $\begin{array}{l}0.352 * * * \\
(0.271-0.433)\end{array}$ \\
\hline COVID \% & & & & & $\begin{array}{l}0.048 \\
(-0.042-0.139)\end{array}$ \\
\hline COVID Danger & & & & & $\begin{array}{l}0.250 * * * \\
(0.162-0.339)\end{array}$ \\
\hline \multicolumn{6}{|l|}{ Random Effects } \\
\hline$\sigma 2$ & 3.29 & 0.96 & 0.96 & 0.89 & 3.29 \\
\hline$\tau 00_{\text {state }}$ & 0.52 & 0.00 & 0.00 & 0.00 & 0.51 \\
\hline ICC & 0.14 & 0.00 & 0.00 & 0.00 & 0.14 \\
\hline $\mathrm{N}_{\text {state }}$ & 51 & 51 & 51 & 51 & 51 \\
\hline Observations & 5154 & 4922 & 5171 & 5128 & 4905 \\
\hline $\begin{array}{l}\text { Marginal } \\
\text { Conditional R2 }\end{array}$ & $0.072 / 0.198$ & $0.044 / 0.048$ & $0.040 / 0.043$ & $0.107 / 0.111$ & $0.119 / 0.238$ \\
\hline
\end{tabular}


Table D. Study 2 MLM Analyses with Skew Correction for Models 2-3

\begin{tabular}{|c|c|c|c|}
\hline & $\begin{array}{l}\text { Model } 1 \\
\text { (Mask Use) }\end{array}$ & $\begin{array}{l}\text { Model } 2 \\
\text { (COVID-19 Cases) }\end{array}$ & $\begin{array}{l}\text { Model } 3 \\
\text { (COVID-19 Deaths) }\end{array}$ \\
\hline Predictors & $\beta(95 \%$ CI $)$ & $\beta(95 \%$ CI $)$ & $\beta(95 \%$ CI $)$ \\
\hline Intercept & $\begin{array}{l}0.014 * * * \\
(-0.111-0.138)\end{array}$ & $\begin{array}{l}-0.015 * * * \\
(-0.178-0.148)\end{array}$ & $\begin{array}{l}-0.031 \\
(-0.119-0.057)\end{array}$ \\
\hline Population Density & $\begin{array}{l}-0.039 * * * \\
(-0.062--0.016)\end{array}$ & $\begin{array}{l}-0.014 \\
(-0.038-0.010)\end{array}$ & $\begin{array}{l}-0.01 \\
(-0.040-0.020)\end{array}$ \\
\hline Older Adult Proportion & $\begin{array}{l}-0.016 \\
(-0.040-0.008)\end{array}$ & $\begin{array}{l}-0.167 * * * \\
(-0.192--0.142)\end{array}$ & $\begin{array}{l}0.122 * * * \\
(0.091-0.154)\end{array}$ \\
\hline Education Attainment & $\begin{array}{l}0.151 * * * \\
(0.118-0.184)\end{array}$ & $\begin{array}{l}-0.192 * * * \\
(-0.228--0.157)\end{array}$ & $\begin{array}{l}-0.192 * * * \\
(-0.236--0.148)\end{array}$ \\
\hline Personal Income & $\begin{array}{l}0.012 \\
(-0.018-0.042)\end{array}$ & $\begin{array}{l}0.039 * \\
(0.007-0.071)\end{array}$ & $\begin{array}{l}-0.01 \\
(-0.049-0.029)\end{array}$ \\
\hline Income Inequality & $\begin{array}{l}-0.059 * * * \\
(-0.084--0.033)\end{array}$ & $\begin{array}{l}0.069 * * * \\
(0.042-0.096)\end{array}$ & $\begin{array}{l}0.061 * * * \\
(0.027-0.094)\end{array}$ \\
\hline Religious Adherents & $\begin{array}{l}-0.092 * * * \\
(-0.116--0.067)\end{array}$ & $\begin{array}{l}0.171 * * * \\
(0.145-0.197)\end{array}$ & $\begin{array}{l}0.077 * * * \\
(0.044-0.110)\end{array}$ \\
\hline Vaccination Rate & $\begin{array}{l}0.040 * * \\
(0.015-0.066)\end{array}$ & $\begin{array}{l}0.022 \\
(-0.005-0.049)\end{array}$ & $\begin{array}{l}0.008 \\
(-0.025-0.041)\end{array}$ \\
\hline COVID-19 Cases & $\begin{array}{l}0.004 \\
(-0.022-0.030)\end{array}$ & $\begin{array}{l}0.038 * * \\
(0.011-0.066)\end{array}$ & $\begin{array}{l}-0.011 \\
(-0.045-0.022)\end{array}$ \\
\hline COVID-19 Deaths & $\begin{array}{l}0.046 * * * \\
(0.019-0.074)\end{array}$ & $\begin{array}{l}-0.069 * * * \\
(-0.098--0.039)\end{array}$ & $\begin{array}{l}-0.011 \\
(-0.046-0.025)\end{array}$ \\
\hline Mask Mandate & $\begin{array}{l}0.344 * * * \\
(0.215-0.472)\end{array}$ & $\begin{array}{l}-0.174 * \\
(-0.342--0.006)\end{array}$ & $\begin{array}{l}-0.031 \\
(-0.125-0.064)\end{array}$ \\
\hline Religiosity & $\begin{array}{l}-0.168 * * \\
(-0.283--0.053)\end{array}$ & $\begin{array}{l}0.272 * * * \\
(0.124-0.421)\end{array}$ & $\begin{array}{l}0.025 \\
(-0.065-0.115)\end{array}$ \\
\hline Democrat Proportion & $\begin{array}{l}0.300 * * * \\
(0.271-0.329)\end{array}$ & $\begin{array}{l}-0.001 \\
(-0.033-0.032)\end{array}$ & $\begin{array}{l}0.082 * * * \\
(0.042-0.121)\end{array}$ \\
\hline Collectivism & $\begin{array}{l}0.316 * * * \\
(0.195-0.437)\end{array}$ & $\begin{array}{l}-0.360 * * * \\
(-0.516--0.205)\end{array}$ & $\begin{array}{l}0.168 * * * \\
(0.072-0.264)\end{array}$ \\
\hline Mask Use & & $\begin{array}{l}-0.104 * * * \\
(-0.141--0.066)\end{array}$ & $\begin{array}{l}-0.038 \\
(-0.084-0.008)\end{array}$ \\
\hline COVID-19 Cases & & & $\begin{array}{l}0.499 * * * \\
(0.459-0.540)\end{array}$ \\
\hline \multicolumn{4}{|l|}{ Random Effects } \\
\hline$\sigma 2$ & 0.01 & 0.00 & 0.00 \\
\hline$\tau 00$ state & 0.00 & 0.00 & 0.00 \\
\hline $\mathrm{ICC}$ & 0.35 & 0.45 & 0.13 \\
\hline $\mathrm{N}_{\text {state }}$ & 49 & 49 & 49 \\
\hline Observations counties & 3046 & 3046 & 3046 \\
\hline Marginal $\mathrm{R}^{2}$ / Conditional $\mathrm{R}^{2}$ & $0.523 / 0.688$ & $0.367 / 0.654$ & $0.390 / 0.467$ \\
\hline
\end{tabular}

Note: $* p<0.05, * * p<0.01, * * * p<0.001$; COVID-19 cases and deaths were standardized to range from 0 to 1 and then capped at 0.4 and 0.2 , respectively, to eliminate strong outliers. After applying a ceiling correction, skew and kurtosis for cases $(0.910,-0.065)$ and deaths $(0.486,-0.470)$ showed acceptable normality; Shapiro-Wilks residuals test for Models $2(\mathrm{~W}=0.975, p<0.001)$ and $3(\mathrm{~W}=0.971, p<0.001)$ showed improvement over the raw analyses with $\mathrm{W}$ values close to 1 ( $p$ values expected to be significant due to large sample). 